
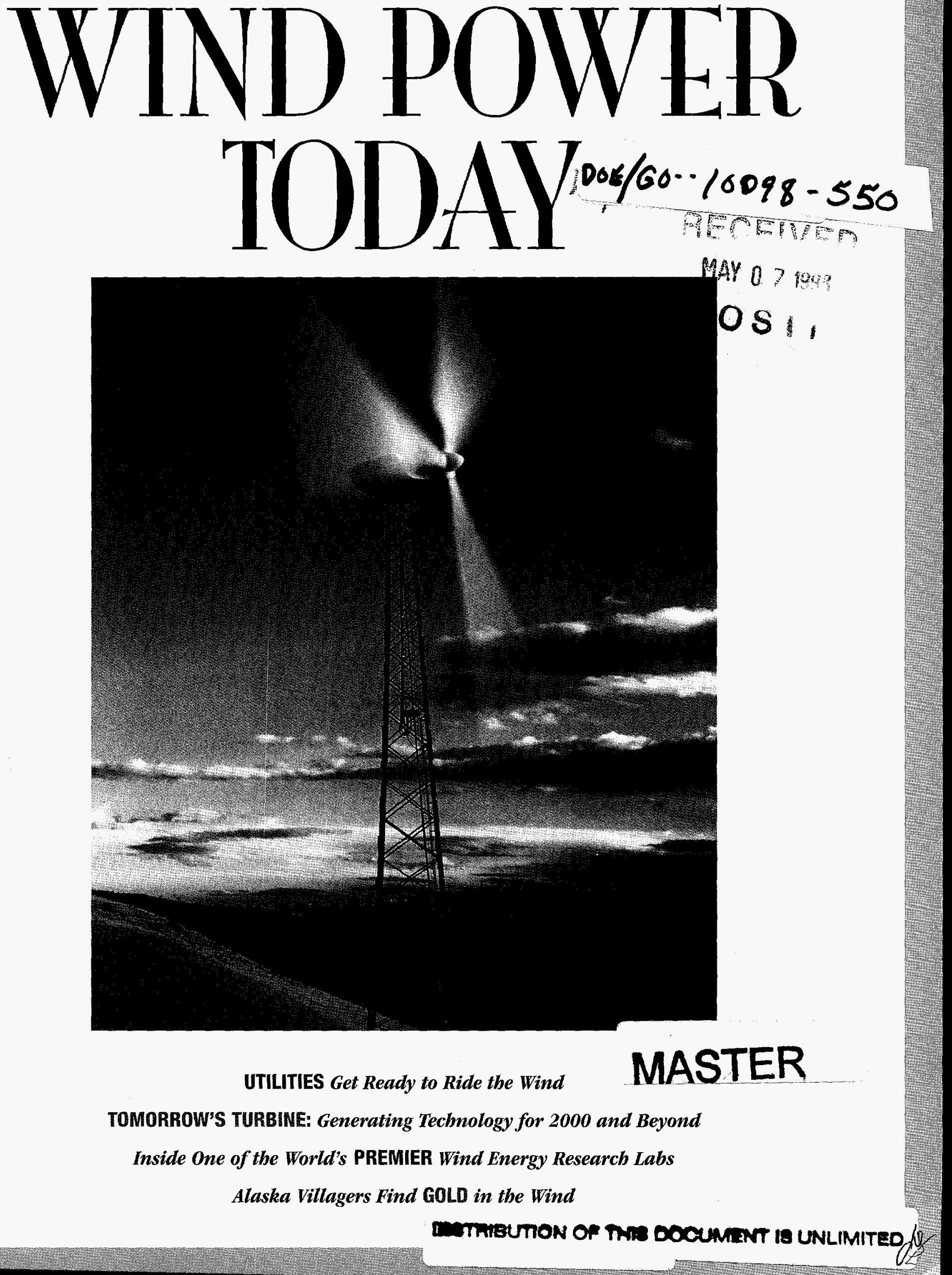


\section{7: THE YEAR IN REVIEW}

\section{January}

The Electric Power Research institute and the U.S. Department of Energy announced that the Utility Wind Turbine Verification Program will expand into new areas of the country. Wind power plants in west Texas and Vermont will be joined by new facilities in Alaska, lowa, Nebraska, New York, Oklahoma, Texas, and Wisconsin.

\section{March}

Engineers at the National Wind Technology Center completed certification tests for the first time in the United States on two U.S. turbines. Wind turbine certification is becoming increasingly important to sell turbines in world markets.

\section{April}

More than 200 participants from around the world attended a Village Power Workshop held in Washington, D.C. The workshop provided information on how wind energy can supply power to the more than 2 billion people who live in remote areas of the world without access to an electric grid.

\section{May}

Researchers at the National Wind Technology Center installed and began testing the lightweight Cannon Wind Eagle 300/30 turbine. The innovative Wind Eagle 300/30 is the most flexible turbine in the world, and it may revolutionize wind turbine design.

\section{June}

At the National Wind Technology Center, U.S. Secretary of Energy Federico Peña and two U.S. companies signed contracts for the design of innovative utility turbines for the next century. The cost-shared contracts are the largest in the history of the federal wind program.

More than 400 people attended the American Wind Energy Association's annual Windpower conference in Austin, Texas. This year's conference was cosponsored by Green Mountain Power Corporation and the U.S. Department of Energy.

Hot topics included how U.S. electric utility restructuring and customer choice will affect wind energy, international markets (wind energy is the world's fastest growing energy technology), and turbine design improvements.

\section{July}

The Utility Wind Interest Group met above the Arctic Circle in Kotzebue, Alaska, for a business meeting and tour of a wind/diesel hybrid system using three new Atlantic Orient Corporation AOC 15/50 wind turbines.

The system is demonstrating the use of wind technology in cold climates.

Enron Wind Corporation began building the largest wind power plant in the Midwest near Lake Benton, Minnesota. Northern

States Power will purchase electricity from the 107-megawatt (MM) facility, scheduled for completion in 1998.

\section{August}

Green Mountain Power Corporation dedicated its new 6-MW wind power plant near Searsburg, Vermont. The facility is the first wind power plant east of the Mississippi River.

\section{September}

PacifiCorp, the Eugene Water and Electric Board, and SeaWest Energy broke ground for a 41-MW wind plant in Carbon County, Wyoming. The Bonneville Power Administration, which is part of the U.S. Department of Energy, will buy nearly $40 \%$ of the power produced by the facility to offset reduced hydropower generation.

\section{October}

Public Service Company of Colorado announced that nearly 4,000 customers had signed up for Windsource. Participants in the program will pay $\$ 2.50$ extra for every 100 kilowatt-hours of electricity produced by the utility's 10-MW Ponnequin Wind Facility, under construction near the Colorado-Wyoming state line. 


\section{DISCLAIMER}

This report was prepared as an account of work sponsored by an agency of the United States Government. Neither the United States Government nor any agency thereof, nor any of their employees, make any warranty, express or implied, or assumes any legal liability or responsibility for the accuracy, completeness, or usefulness of any information, apparatus, product, or process disclosed, or represents that its use would not infringe privately owned rights. Reference herein to any specific commercial product, process, or service by trade name, trademark, manufacturer, or otherwise does not necessarily constitute or imply its endorsement, recommendation, or favoring by the United States Government or any agency thereof. The views and opinions of authors expressed herein do not necessarily state or reflect those of the United States Government or any agency thereof. 


\section{DISCLAIMER}

Portions of this document may be illegible electronic image products. Images are produced from the best available original document. 


\section{About "Wind Power Today"}

THE WORD THAT BEST DESCRIBES WIND POWER TODAY IS ADAPTABILITY. This issue of "Wind Power Today" describes how, in a changing world, wind energy has proven to be an adaptable electricity generation source, able to meet technical challenges, succeed in harsh operating environments, and grow despite uncertainty in the U.S. electric utility industry posed by restructuring. In 1997, utilities from Alaska to Vermont used new wind turbines to make clean electricity for their customers, while many utilities across the country measured their winds to see if they might be strong and steady enough to power wind turbines. Worldwide, wind continued as the fastest growing energy technology in 1997; today wind energy markets top $\$ 1.5$ billion a year. To ensure that U.S. technology can meet new challenges and compete with the best in the world, the U.S. Department of Energy's (DOE's) Wind Energy Program sponsors research and development at the National Renewable Energy Laboratory (NREL) and Sandia National Laboratories. The heart of DOE's program is NREL's National Wind Technology Center, respected worldwide for its turbine testing, research, and innovation. In 1997 , DOE and its labs helped U.S. utilities to adapt wind energy to meet their specific needs, worked with industry to adapt turbine technology for tomorrow, and carried out basic research. Despite the ever-changing physical, political, economic, institutional, and cultural environment in which wind turbines operate, the ability of wind energy to keep adapting and generating clean, low-cost electricity remains a constant.

\section{Contents}

2

Green Mountain Power Dedicates First

U.S. Wind Power Plant East of the Mississippi

12

A New Generation of Wind Turbines on the Horizon

22

The National Wind Technology Center

24

Alaska to Harness Arctic Winds for Village Power

MASTER

32

The Federal Wind Energy Program 


\section{Green Mountain Power}

\section{Dedicates First}

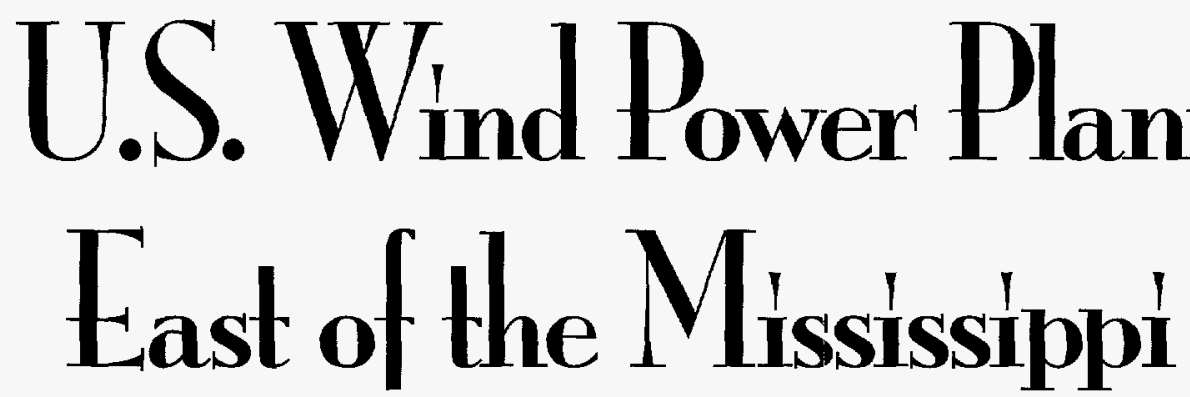

\section{AS WHITE CLOUDS DRIFTED ACROSS THE BLUE SKY ABOVE SOUTHERN VERMONT,}

Green Mountain Power Corporation celebrated the completion of the first wind power plant east of the Mississippi River. During a warm August weekend, visitors from all over the country were treated to the breathtaking view of eleven 550 -kilowatt $(\mathrm{kW}) \mathrm{Z}-40$ wind turbines towering above a horseshoe-shaped ridge near Searsburg. With black blades glistening atop 129-foot tubular towers, the turbines looked more like visitors from the future than a power plant. Exotic though they may be today, pollution-free wind power facilities will likely be a familiar sight in the coming years.

On August 15, 1997, Green Mountain Power was joined by Senators James Jeffords and Patrick Leahy, Dan Reicher, U.S. Department of Energy (DOE), and others in dedicating the 6-megawatt (MW) wind power plant at Waldo Mountain. In honor of the dedication, Dr. Howard Dean, Vermont's governor, proclaimed August 16th Wind Energy Day.

Two days before the dedication, Green Mountain Power employees began a 120 -mile road relay from utility headquarters in South Burlington to the power plant at Searsburg. Chief Executive Officer (CEO) Christopher Dutton and former CEO Douglas Hyde ran two legs of the relay. A miniature wooden wind turbine was passed through the hands of more than two dozen other runners until Dorothy Schnure, the company's public relations director, sprinted to the turbines on Saturday morning. During the weekend, more than 1,000 people toured the wind facility. And, nearby Wilmington held a fair featuring wind energy exhibits, crafts, and games.
Those on the tour, most of whom were Vermont residents: were thrilled that the new facility is providing pollution-free electricity to more than 2,000 homes. That's 14 million kilowatt-hours a year in normal wind conditions. Because the utility won't need to use fossil fuel to make that electricity, Vermont will reduce its greenhouse-gas emissions by 22 million pounds a year.

Green Mountain Power was careful to protect the forest and local wildlife when it built the wind power plant. Studies prior to construction showed that relatively few trees would need to be removed to build the facility and that the remaining trees would have little impact on the winds available to the turbines. Consequently, construction crews cleared only 40 acres of the 280-acre site to build an access road, erect transmission lines, install the turbines, and build a substation. Except for the substation and road, the entire area will be allowed to "brush in" and return to its natural state. 







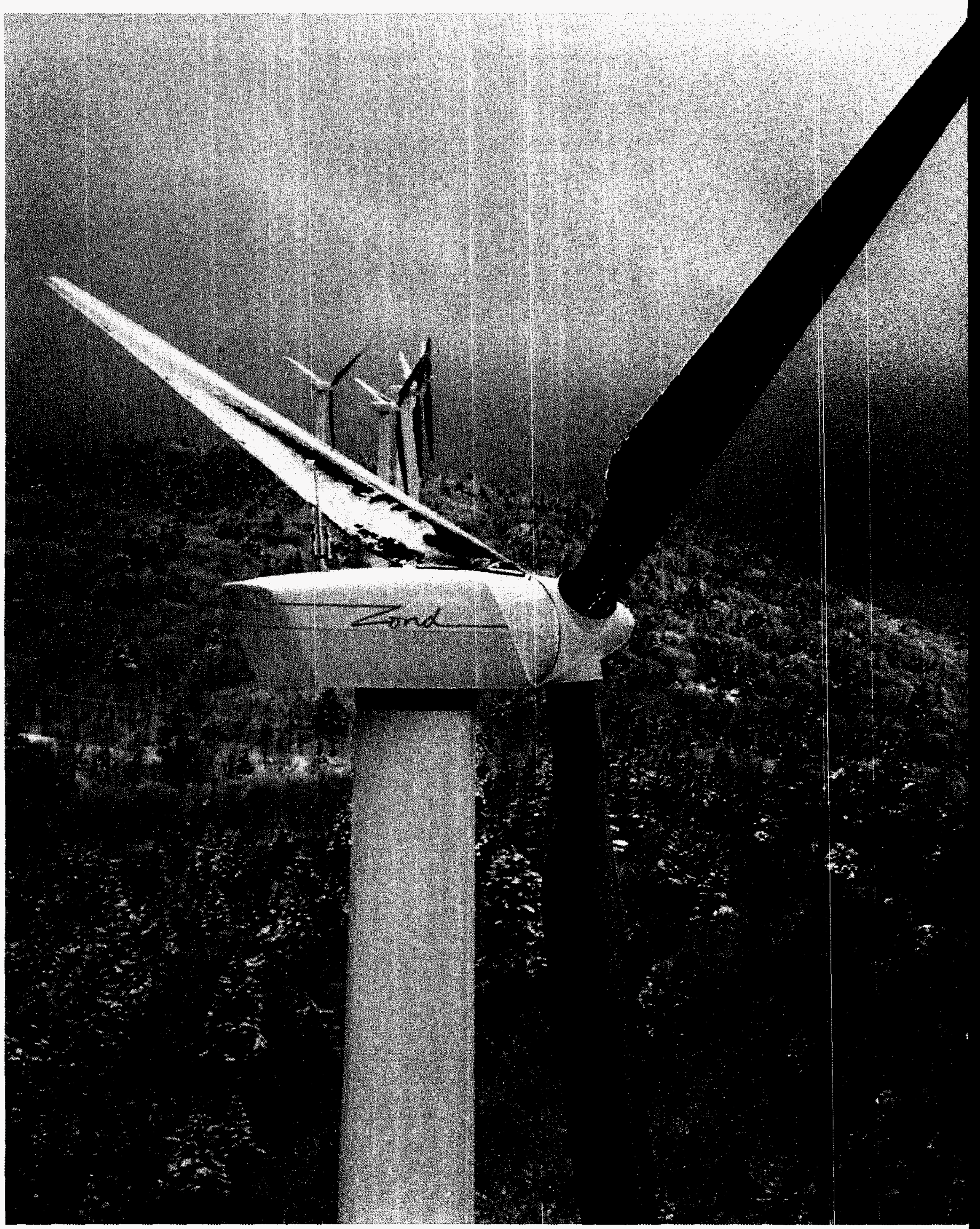

Construction crews cut as few trees as possible to build the Searsburg wind power plant. Now that construction is complete, the area around the tur 


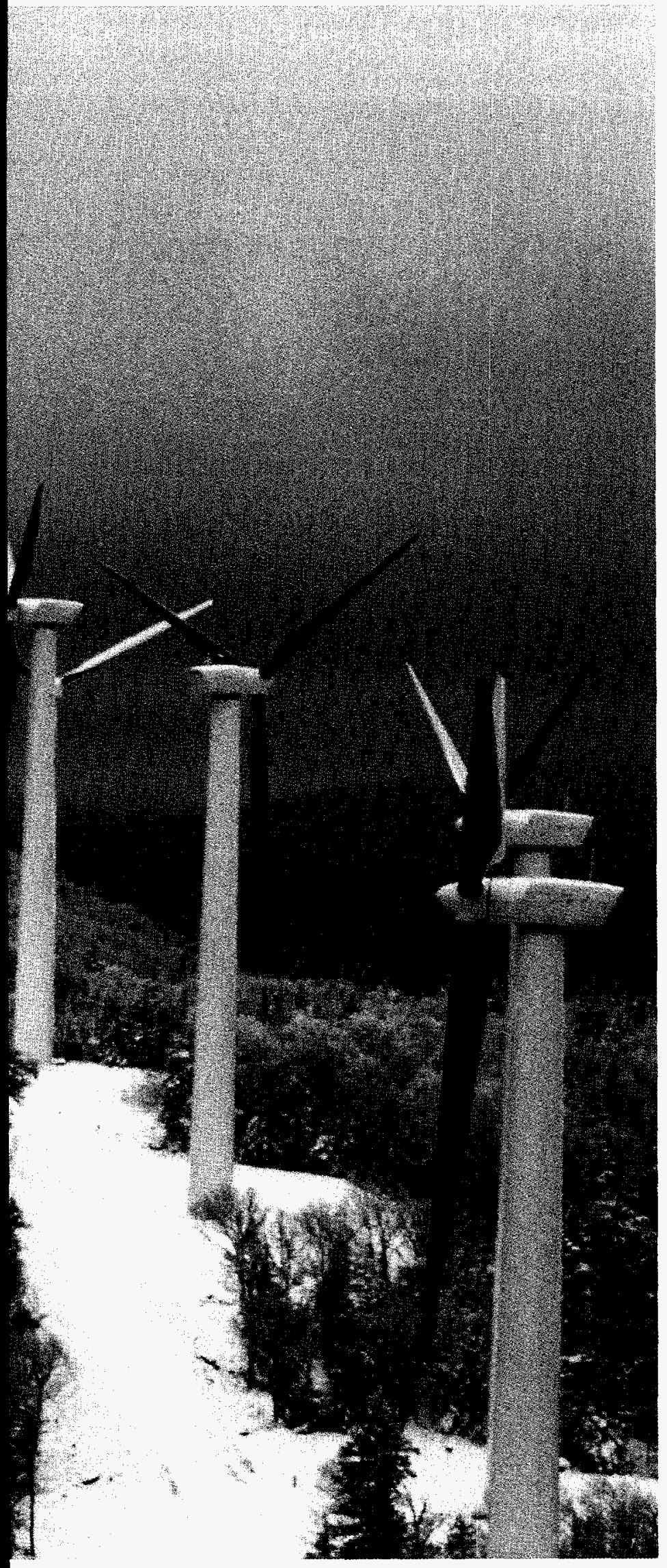

ng allowed to "brusb in" and return to its natural state.
To limit the impact of the wind facility on wildlife, Green Mountain Power studied bear and bird populations before, during, and after construction. The utility also agreed to schedule construction and maintenance to minimize their effects on black bear habitat.

"We're confident the wind facility will have no major impacts on bears, birds, or the environment," says John Saintcross, director of resource portfolio management for Green Mountain Power. "The forests here are a treasured commodity." The warm reception Vermonters gave the wind power plant is a testament to the attention Green Mountain Power paid to the environment and to public concerns during planning and construction.

\section{UTILITY WIND TURBINE VERIFICATION PROGRAM HELPS UTILITIES EXPLORE WIND POWER}

The Searsburg facility is the second wind power plant completed under the auspices of the Utility Wind Turbine Verification Program (TVP) sponsored by DOE and the Electric Power Research Institute (EPRI). The first facility was a 6.6-MW facility built in 1995 in west Texas near Fort Davis by Central and South West Services, Inc.

One of the turbine verification program's goals is to build a bridge between DOE's wind turbine development efforts and utilities considering using wind to generate electricity. DOE helps U.S. companies develop high-performance wind turbines for global energy markets.

The turbine verification program helps utilities understand the benefits and challenges of using wind power by giving them the opportunity to operate wind power plants. Utility managers are not used to operating a wind power plant in conjunction with other power generation sources. Unlike fossil fuels, for instance, wind is an intermittent resource that is not always available. Figuring out how to capture the wind when it is present and replace it with power from another source when it disappears is a challenge. But wind energy offers advantages that other power plants do not, such as free fuel (the wind) and no air emissions.

For Green Mountain Power and Central and South West Services, the key issues in deciding to build a wind power facility were financing and finding the best technology. The turbine verification program offered the utilities a way to get hands-on experience with new wind technologies without assuming undue financial risk. The program also allowed the utilities to obtain technical support from the National Wind Technology Center (NWTC). 


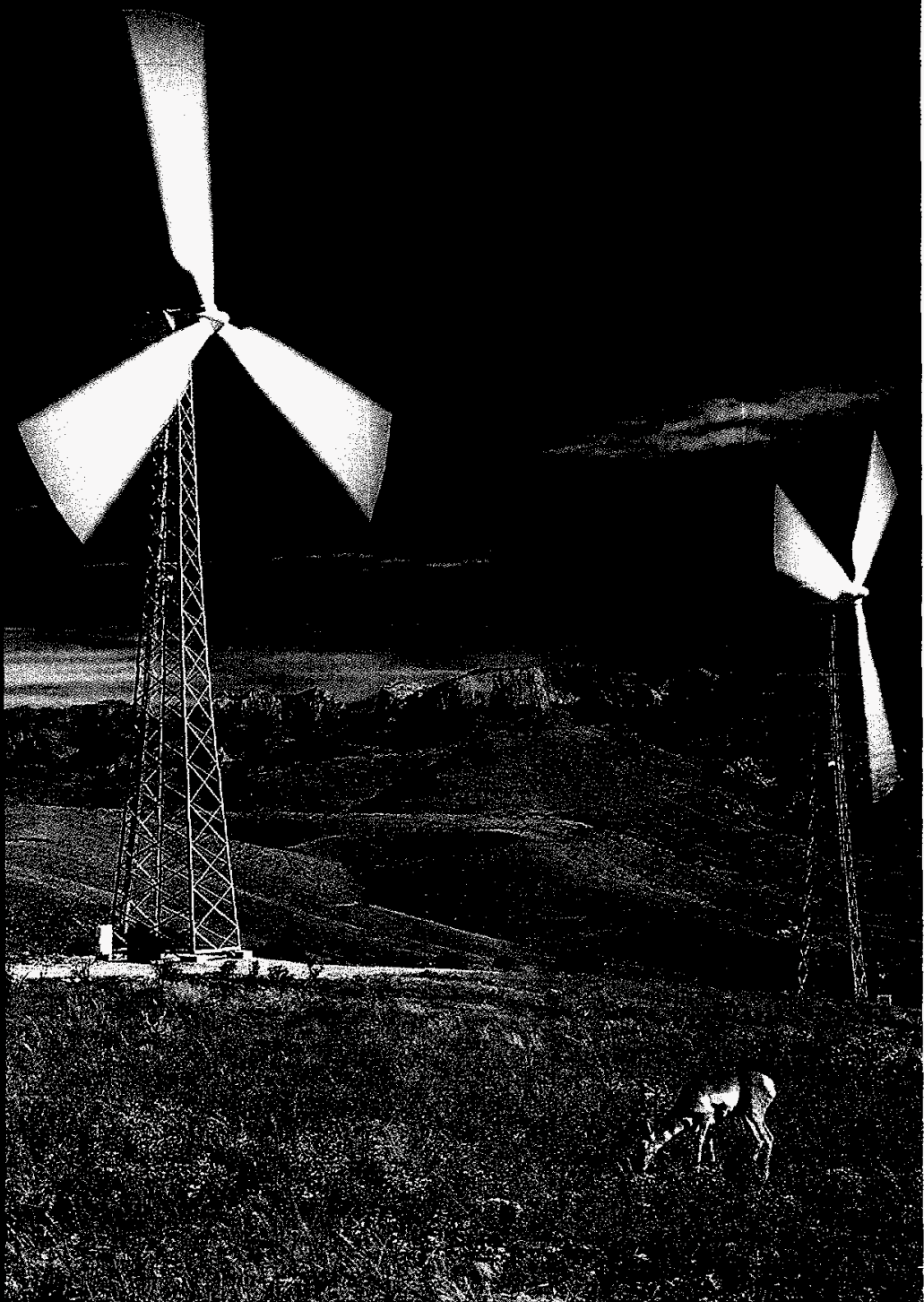

Central and South West Services, Inc., operates a 6.6-MW wind power plant in west Texas near Fort Davis. The facility was the first of its kind completed as part of the turbine verification program.

To build its facilities, Green Mountain Power received $\$ 2.25$ million from DOE and $\$ 1.73$ million from EPRI while Central and South West received $\$ 1$ million from DOE and $\$ 4.4$ million from EPRI. Both utilities are participating in three-year studies of wind plant operations. For Green Mountain Power, the financial support from the turbine verification program made it possible for the utility to realize a long-standing dream of building a wind power facility.

"For us, the TVP was a great opportunity," says Saintcross. "It was a natural fit. We've had an active wind research program since the 1970 s, and the TVP allowed us to build a wind power plant sooner than we otherwise would have. It was great timing

"When the TVP was announced [in 1992], we leapt at the chance to do a wind project in a harsh climate," he adds. "We knew the upper Midwest would have ice and snow. What we're learning in Vermont will have value not just for us, but also for wind development in the Midwest [with its extensive wind resource]."
The machines used at Fort Davis were the first 12 commercial Z-40 turbines manufactured by Zond Systems, Inc., of Tehachapi, California. Zond is a subsidiary of Enron Wind Corporation, a subsidiary of Enron Renewable Energy Corporation. The 11 turbines installed at Searsburg brought the total number of installed commercial Z-40 turbines to 23. Like many new technologies in the early stages of commercialization, there have been problems to solve. For instance, Zond learned an important lesson from the Texas wind facility: Lightning can wreak: havoc with a wind turbine.

"The main construction of our wind power plant occurred during the summer, which is our peak lightning season," says Brian Champion, former renewable site supervisor for Central and South West. "We had a generator on one turbine destroyed by lightning before that turbine ever operated. That was a little hint that something was not quite right."

Even when the turbines were properly grounded, lightning strikes occasionally damaged motors on the turbine and knocked out communication links between the turbines and the power plant's opera tions center.

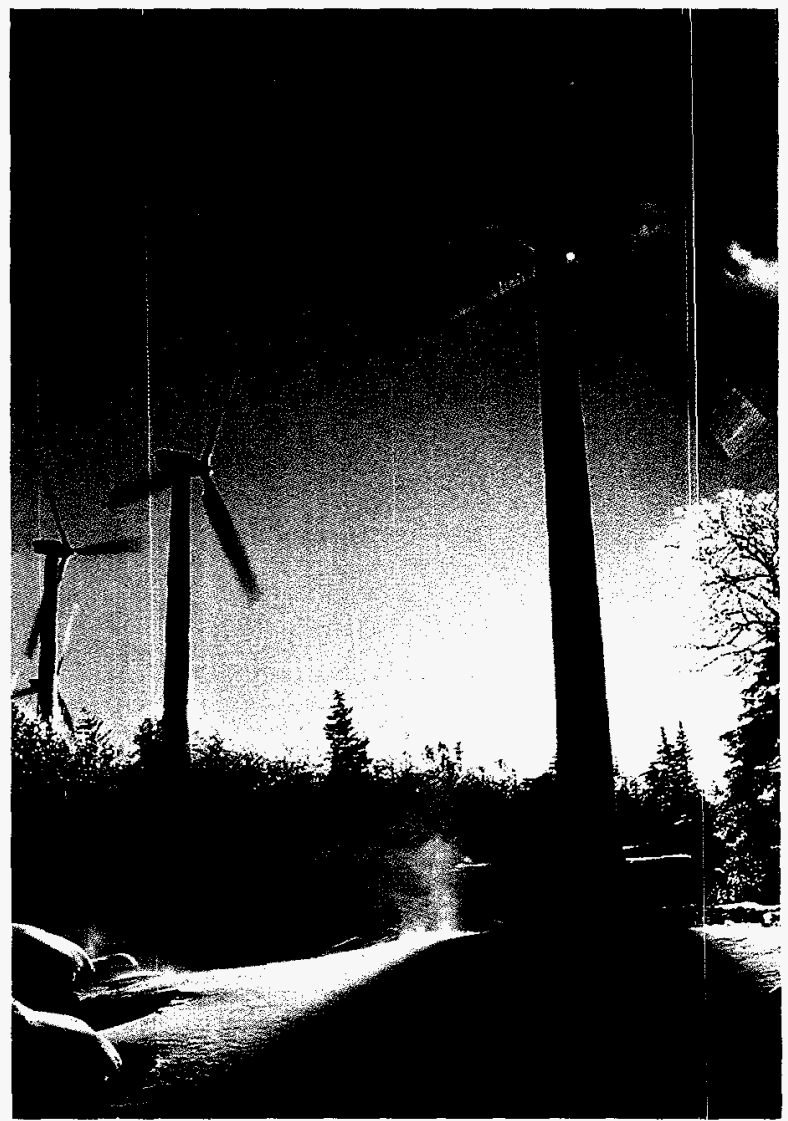

The turbine verification program offered Green Mountain Power a chance to learn about wind generation in a wet, cold climate. The lessons learned in Vermont are expected to encourage Midwestern utilities to invest in wind power. 


\section{HOW THE Z-40 WIND TURBINE MAKES ELECTRICITY}

The Z-40 has three blades that are each nearly 64 feet long - about the height of a four-story building. When attached to a central hub, they form the turbine rotor, an essential component for generating electricity from the wind: As the rotor turns, it turns the turbine's main shaft, also attached to the hub. The main shaft is connected to a generator through a series of gears, which increase the speed of rotation from about 60 revolutions per minute (rpm) to as much as $1,200 \mathrm{rpm}$. This is the speed at which the generator produces 60 -cycle alternating current.

When the wind speed is 30 miles per hour (mph) or higher, the turbine produces 550 kilowatts of electricity.
At lower wind speeds, less electricity is produced. If the wind speed falls below eight mph, electricity production ceases, and the turbine shuts itself off. To protect blades and other components from damage, the turbine also shuts itself off when wind speeds exceed $65 \mathrm{mph}$. However, as a safety precaution, the turbine is built to withstand hurricane-force winds of more than $150 \mathrm{mph}$

Turbine components also include a sophisticated, computerized controller, cables that carry electricity to the feeder line into the substation, cables that connect the controller to a central power plant control system, and a yaw drive. The yaw drive rotates the turbine into and out of the wind in response to infor- mation about wind direction from a wind vane on top of the nacelle. The nacelle is a cover that protects turbine components. It is located behind the rotor. The rotor and nacelle sit atop either a tapered tubular or lattice tower 129 feet tall.

The Z-40 turbines used in Vermont and west Texas are similar, except for blade design. The Texas turbines have aileron controls, which are similar to flaps on an airplane wing. The ailerons regulate rotor speed and power production. The Vermont turbines control rotor speed and modulate power output by changing the angle of the blades with respect to the wind. The ability to change the angle of the entire blade is known as full-span pitch control.
The problem with lightning was not anticipated by the turbine manufacturer based in California, where the Z-40 prototypes were tested. Storms in California are paltry in comparison with the frequent, severe thunderstorms that move across the plains of west Texas during the summer.

"We've done studies of lightning strikes within a 300-mile radius of our wind facility," Champion says. "On occasion, we've seen 300 strikes a minute."

Working with the NWTC and the National Lightning Safety Institute, Central and South West and Zond found ways to alleviate the problem. They worked together to install an electronic lightning protection system in the communications cables and create better grounding around the turbines. Each turbine is now surrounded by an irrigated trench filled with copper straps and bentonite, a highly absorbent type of clay. Since the trenches were installed, the facility has not lost any major equipment such as motors to lightning.

Central and South West's Manager of Technology Development Ward Marshall is excited about solving the lightning problem.

"The best lightning/wind energy research center in the world is in Fort Davis, Texas," he boasts. "No one in the world has studied lightning to the degree we have at our wind farm." Thanks to the turbine verification program, utilities throughout the Great Plains will be able to reap the benefits of Central and South West's experience.

The turbine manufacturer also profited from the experience.
"The turbine verification program has been very valuable for us," says Dr. Amir Mikhail, vice-president of engineering at Zond. "It allowed us to move quickly from a prototype unit into full production. At the same time, we've been able to see how our machine operates in different environments."

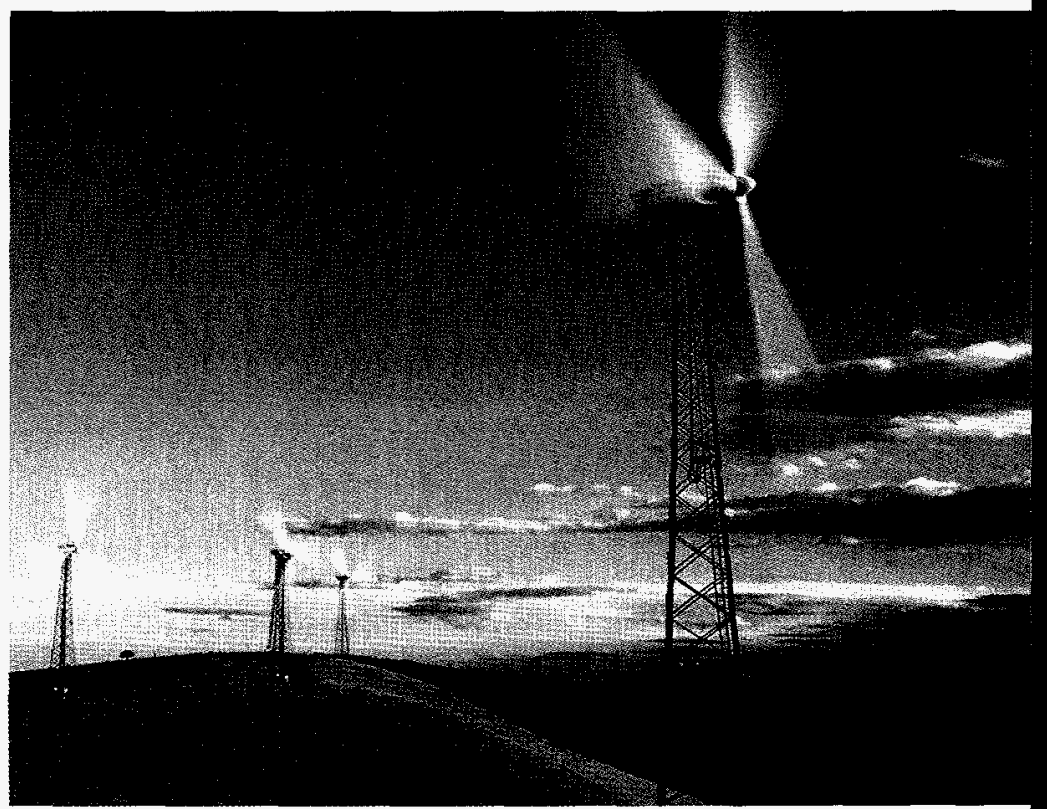

In the Great Plains, lightning can wreak havoc with wind turbines. Central and South West Services and Zond Systems, Inc., learned this lesson the bard way in Texas. The companies have since created state-of-the-art lightning protection systems for wind power plants. 
Green Mountain Power faced its own challenges in Searsburg, many related to the cold and wet New England winters. During the winter, for instance, frost would form on the inside of turbine covers (nacelles) when the turbines weren't operating. Then when it melted, water would fall on equipment, creating problems with corrosion. Adding heaters inside the nacelle solved the problem.

Green Mountain and Zond worked together to tailor Vermont's Z-40 turbines for cold-weather operation. The turbines were outfitted with black blades to soak up the sun's energy. Warm blades help prevent ice buildup. The blades were also given a Teflon $^{\mathrm{TM}}$ coating, which helps keep snow and ice from sticking to them. Heaters were installed for the control system and cold-sensitive fluids such as the hydraulic fluid. Special lubricants designed for cold temperatures were also selected for the turbines.

The tubular towers were made of coldtemperature steel, which maintains its strength even when temperatures fall to $-40^{\circ} \mathrm{F}$. Ladders on the inside of the towers permit maintenance personnel to climb up to the turbine protected from the cold and wind. Finally, Zond designed the nacelle to be large enough to protect workers servicing the turbine during inclement weather.

Green Mountain Power and Central and South West will share the lessons they've learned with other utilities in upcoming years. EPRI completed a comprehensive report on the Searsburg wind power project in December 1997. The institute has issued two reports on the Central and South West facility, one in 1996 and another in 1997. The reports are available to utilities interested in operating their own wind power plants.

\section{UTILITIES TAKE ON NEW}

WIND POWER PROJECTS

EPRI and DOE continue to support new utility participation in the turbine verification program. In January 1997, EPRI announced that more than a dozen utilities will take part in five projects to evaluate advanced wind technologies. The projects will be located in Iowa, Nebraska, New York, Texas, and possibly Oklahoma. The projects will be smaller than the Vermont and Texas wind power plants, and will be linked directly to utility distribution lines.

The smaller facilities will be similar to ones in Europe where land is often hard to come by. Wind installations consisting of two or three turbines have accounted for a significant portion of wind development in Denmark, for example. EPRI and DOE are encouraging utilities to experiment with turbine clusters because they want to show that both large wind power plants and small, distributed wind systems are candidates for future wind development in the United States.

"We want to check out whether distributed clusters of wind turbines will have a market in the United States," explains Ed DeMeo, manager of renewables at EPRI. "We want to know what they cost compared to large installations." DeMeo says that although the jury is still out on the value of distributed wind systems, he believes both wind power plants and turbine clusters will make sense for utilities in the future.

The majority of the five new TVP projects had selected turbines and locations for their turbine clusters by December 1997. EPRI expects nost of them to have turbines in operation by the end of 1998. Cedar Falls Utilities, Algona Municipal Utility, and municipal utilities in Ellsworth, Esterville, Fonda, Montezuma, and Westfield will own and operate three $750-\mathrm{kW} \quad \mathrm{Z}-50$ wind turbines in Algona, Iowa. This will be the first commercial installation of the Z-50 turbine, developed by Zond for regions with moderate wind resources such as

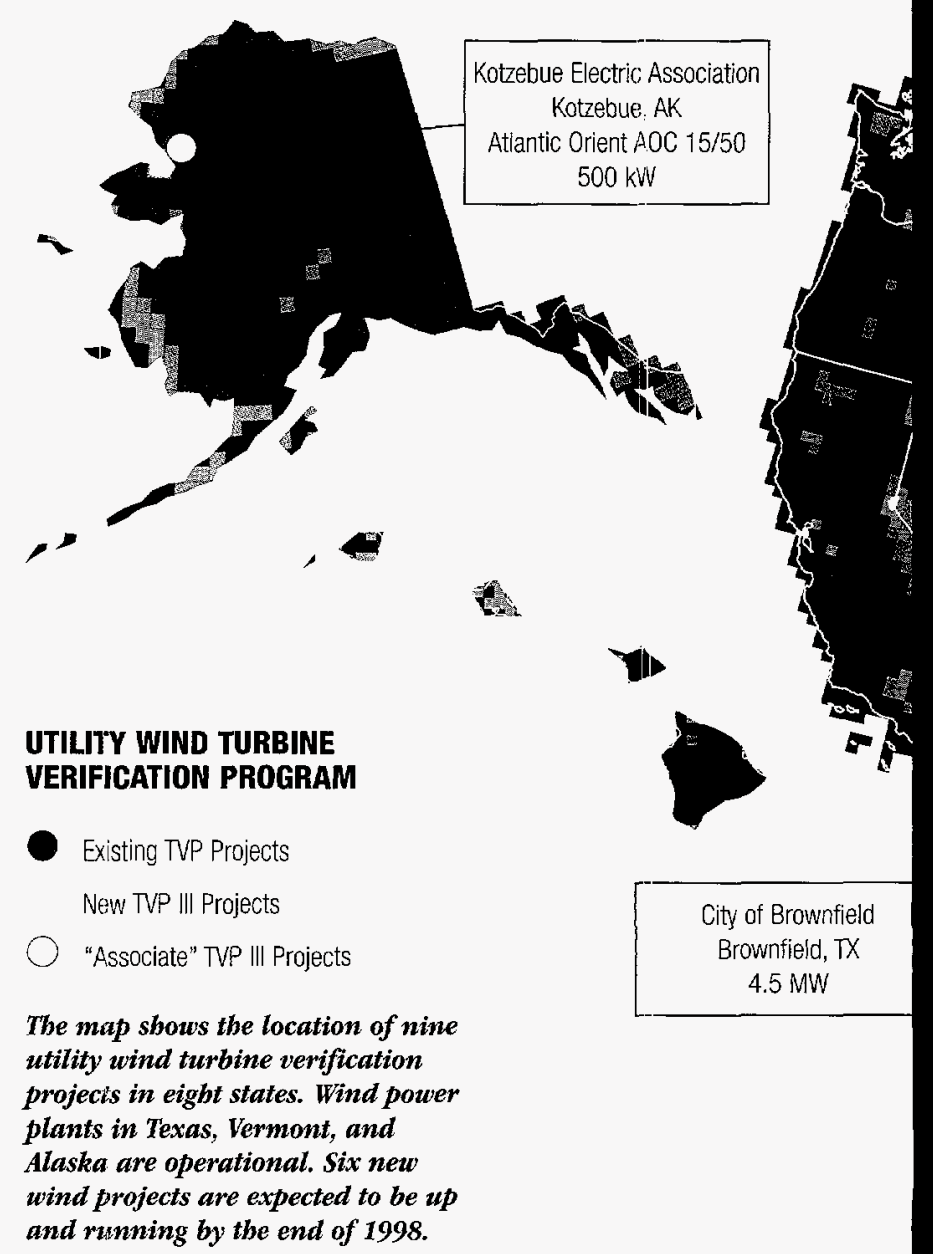


Iowa. EPRI expects the Iowa utilities to gain invaluable experience operating their Z-50 turbines, the largest commercial turbine manufactured in the United States.

"When new utilities come into the turbine verification program, many will have little or no experience with wind power," says Chuck McGowin, manager of wind power at EPRI. "If they decided to build a wind project by themselves, they would have to learn everything from scratch. The process would take longer and be more expensive for them." In Iowa, for example, seven utilities pooled their resources to participate in one small wind project.

The Nebraska Public Power District, Lincoln Electric System, the Cities of Grand Island and Auburn, the Municipal Energy Agency of Nebraska, and the KBR Rural Public Power District will own and operate two Zond Z-48 wind turbines in Springview, Nebraska, which is near the South Dakota border. The new Z-48 turbine is similar to the Z-50, except it has a smaller rotor better suited to Nebraska's more energetic wind resource. The Nebraska Public Power District spearheaded the project after participating in the Utility Wind Resource Assessment Program, sponsored by DOE. The assessment program helps utilities evaluate the wind in locations under consideration for wind development.

"From participating in the wind resource assessment program, we knew we had a good wind resource in the north-central part of the state," explains Frank Thompson, project coordinator for the Nebraska Public Power District. "We're very interested in wind power, and taking part in the turbine verification program is a good way to get our feet wet."

The Nebraska consortium hopes to learn how to operate and maintain commercial wind turbines and understand the impact of wind turbines on an electrical distribution system. Lightning may be a major challenge for the project.

"We need to figure out how to keep the wind turbines protected and keep lightning out of our distribution system," Thompson says. Thanks to Central and South West's experience in Texas, however, the Nebraska utilities won't be starting from scratch to solve lightning-related problems.

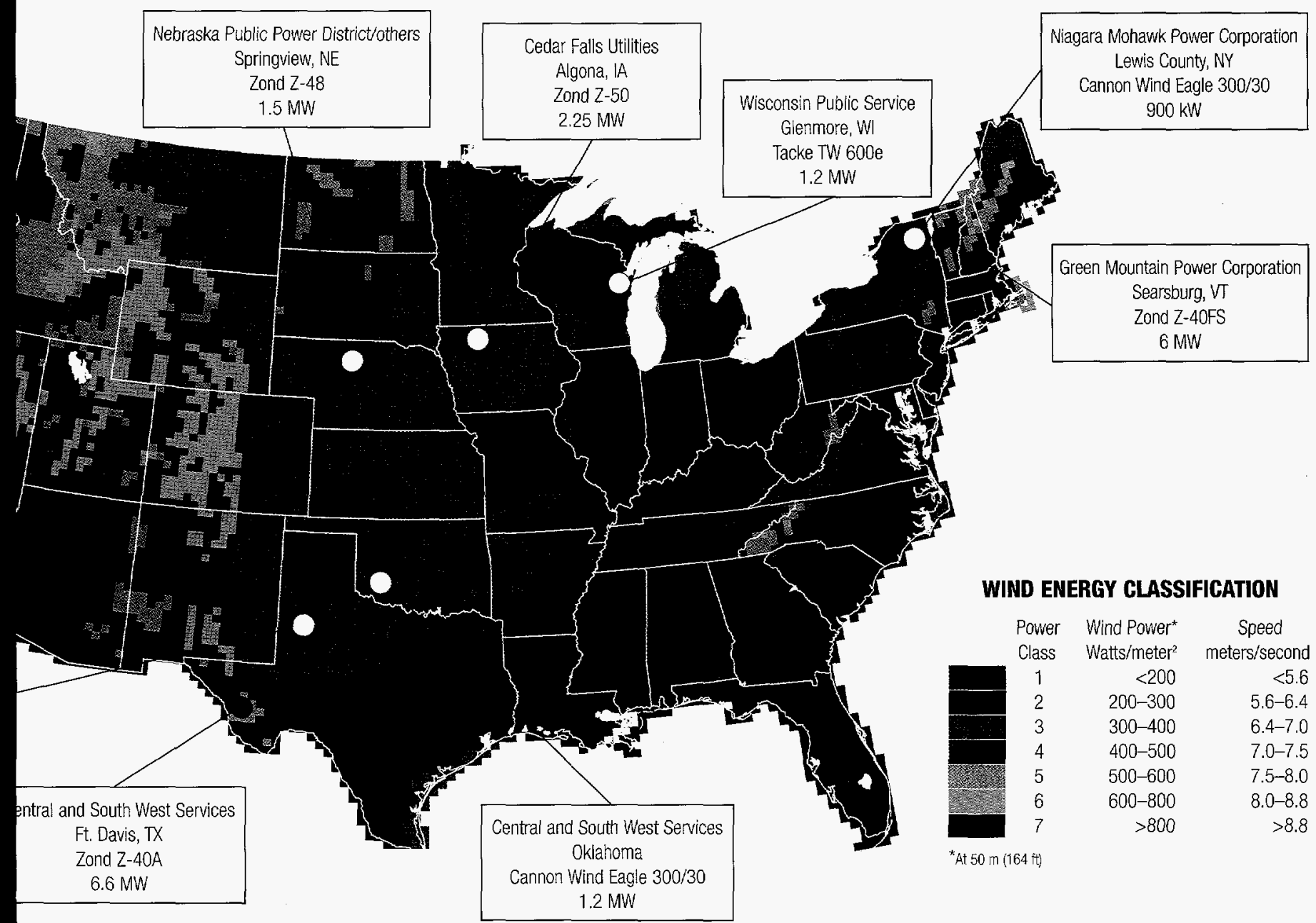


Central and South West will build a 1.2-MW wind plant in either Texas or Oklahoma. The utility is currently prospecting for wind sites in Oklahoma, a state that also experiences powerful summer thunderstorms. Once the site is selected, the utility plans to operate and test four $300-\mathrm{kW}$ Cannon Wind Eagle 300/30 turbines, currently under development by Cannon Wind Eagle Corporation in Tehachapi, California. In a similar project, Niagara Mohawk Power Corporation plans to operate three Cannon Wind Eagle 300/30 turbines in northern New York. In New York, the turbines will operate in a harsh environment that is very cold and receives unusual amounts of snowfall.

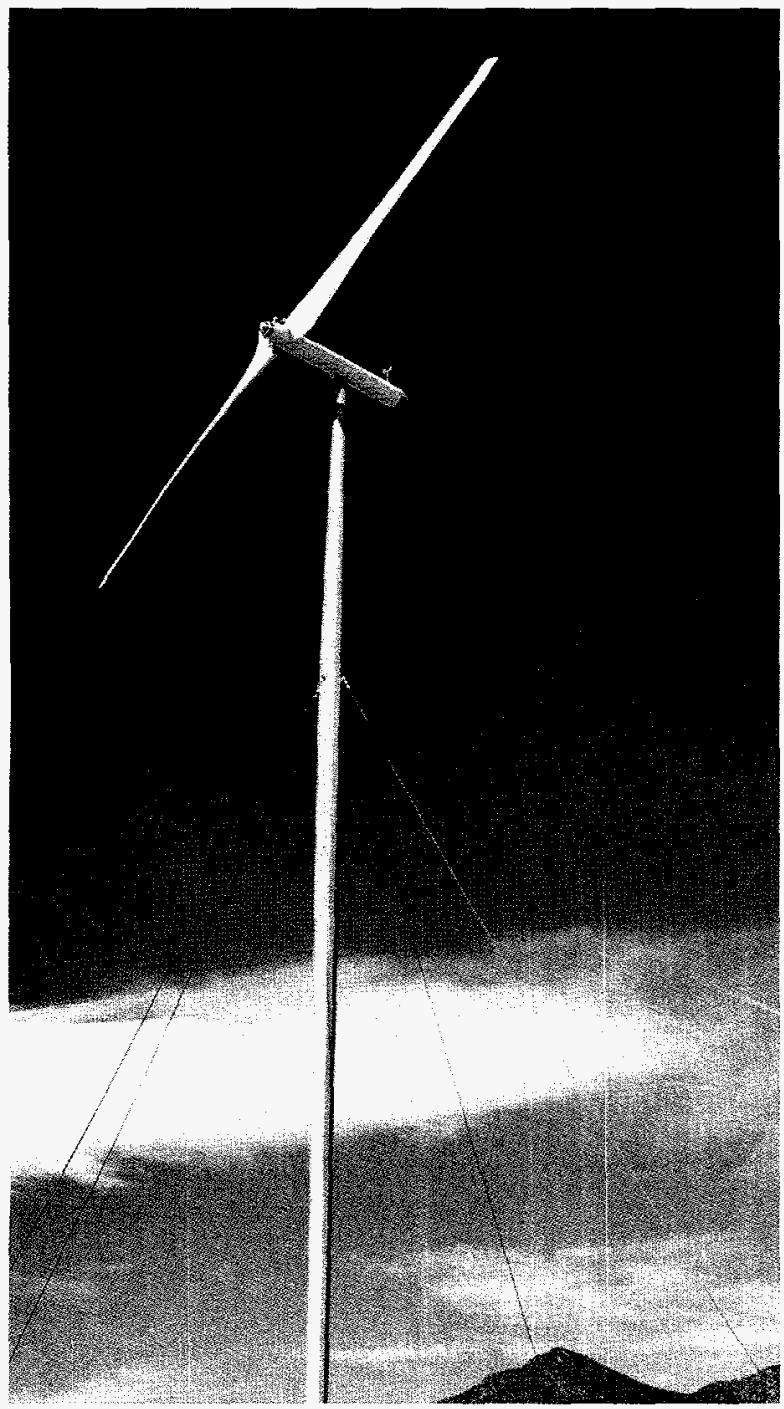

The Cannon Wind Eagle 300/30 sbown above will be commercially operated for the first time as part of the Utility Wind Turbine Verification Program. Central and South West Services plans to operate and test four turbines in Texas or Oklaboma. Niagara Mohawk Power Corporation plans to operate three in northern New York. The turbine is being developed by Cannon Wind Eagle Corporation in Tehachapi, California.

\section{THE CANNON WIND EAGLE 300/30 TURBINE}

The Cannon Wind Eagle is an innovative, lightweight, and flexible turbine. It has a 95.4-foot-diameter rotor that sits on top of a 165 -foot tower. The tall, thin tower is held in place with guy wires. It can be tilted down to the ground for maintenance and back up for operation.

The Cannon Wind Eagle is undergoing comprehensive design testing and evaluation at the National Wind Technology Center. The new turbine will benefit from being operated in a real utility environment where turbine operators will evaluate its energy production, availability, reliability, and operations and maintenance costs.

Beginning in the summer of 1998 , municipal utilities in the cities of Brownfield and Lubbock, Texas, will use electricity from six $750-\mathrm{kW}$ wind turbines. Texas Windpower Company will install and operate three turbines in each community. Brownfield City Manager Dick Fletcher initiated the project for both towns.

"My interest in wind goes back 20 years to when I first came into the city administration," he says. "We submitted a proposal to the Department of Energy to be a site for a 2-MW wind turbine. We didn't get the project."

Fletcher said the idea of developing wind lay dormant for more than 15 years. Then, walter Hornaday, president of Texas Windpower, approached the City of Brownfield in 1995 with the idea of developing wind power as part of a "greenpricing" program. Green-pricing programs offer customers the opportunity to pay premium prices for electricity produced from clean and renewable resources such as the sun or wind.

"I almost laughed," recalls Fletcher. "Our customers want cheaper power. I told Walt that the tree-huggers in Austin or California might go for the idea, but it wouldn't fly in west Texas." Nevertheless, Hornaday's proposal got him thinking seriously about wind again.

When Fletcher heard about the turbine verification program a year later, the joint wind project was born. He is excited about getting the turbines up and running this summer in Brownfield and Lubbock. He expects the turbines to create a positive image for this area of Texas.

"There's a lot of wind in the south plains of Texas," he explains. "You almost never see an article about Lubbock or Plainview that doesn't say something about 'windswept,' 'windblown,' or 'dusty.' Now that we're going to use wind to our advantage, we feel we're going to turn around the negative image." 


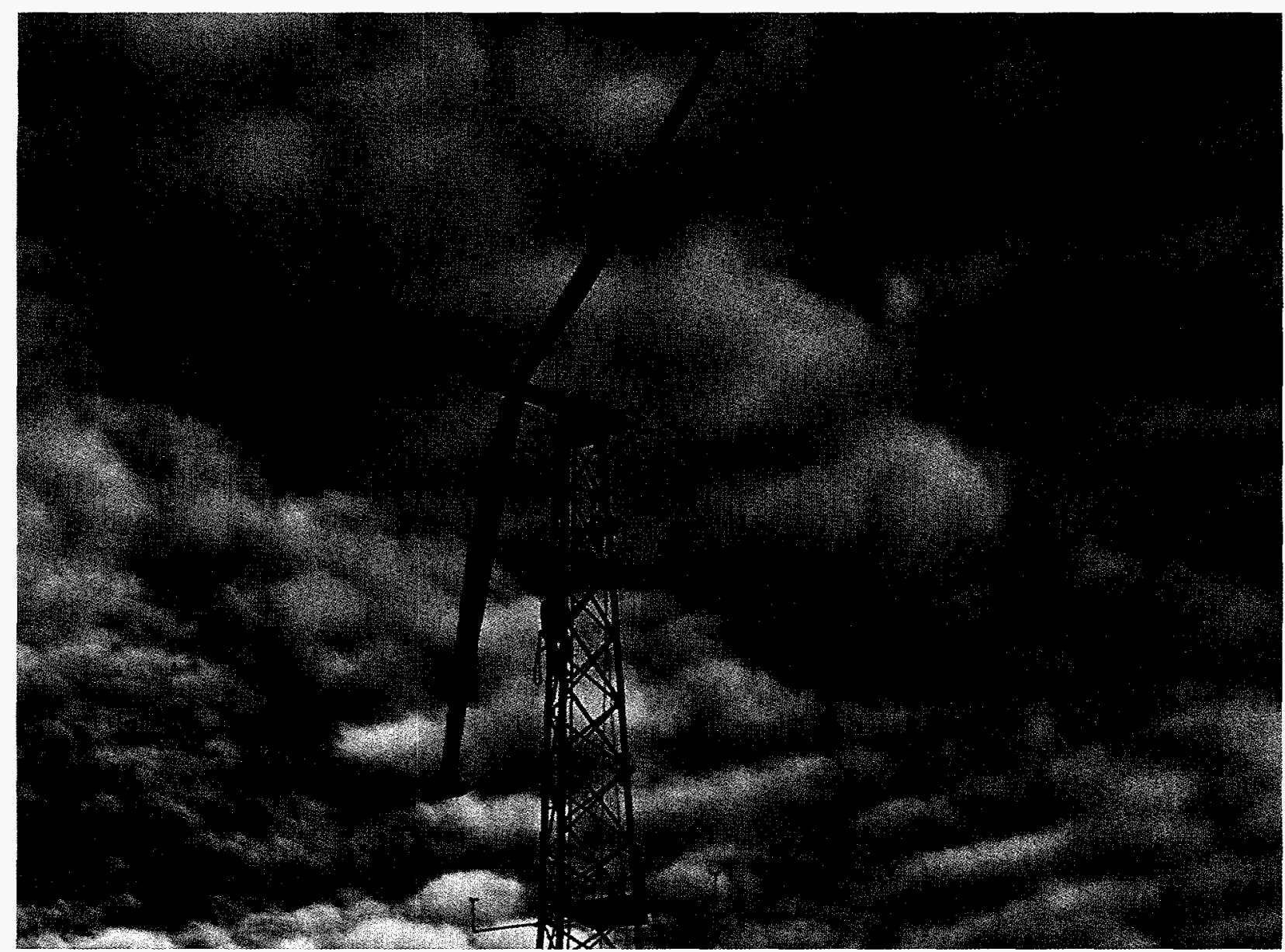

Kotzebue Electric Association operates a wind technology project north of the Arctic Circle in Alaska. The utility is participating in the turbine verification program's testing and evaluation efforts as an "associate" project. Associate projects receive funding from the program for performance evaluation only.

The Brownfield utility is one of many cultivating a positive image by using wind power. Green Mountain Power and Central and South West Services enjoy widespread support for operating innovative wind power plants. By now, they are both "old hands" in the utility wind business. They're not only sharing their experiences with others, but also considering expanding their own investments in this clean and renewable resource.

Two utility wind projects joined the new round of the turbine verification program as "associates," according to EPRI. Associate projects were not given funding to build wind installations, but will receive support for performance evaluation. For example, associates in Glenmore, Wisconsin, and Kotzebue, Alaska, plan to test their new turbines using the same procedures as the regular participants in the turbine verification program. To record wind conditions and turbine responses, all seven projects will use the same type of monitoring equipment, which will be installed and operated by the NWTC. The Alaska wind project is up and running in Kotzebue (see page 24). The Wisconsin project is scheduled to have turbines on line in the spring of 1998.

The turbine verification program has provided important support to the nation's budding wind industry. Zond gained critical experience with its new turbines at Fort Davis and Searsburg. As a result, its parent company, Enron Wind Corporation, was better prepared to undertake its next utility project, a 107-MW wind power plant in southwestern Minnesota. Enron Wind began construction of the Minnesota power plant in July 1997.

In the next couple of years, Zond and Cannon Wind Eagle Corporation will get a chance to test brand-new Z-48, Z-50, and Wind Eagle 300/30 turbines in Iowa, Nebraska, Oklahoma, and New York as part of the turbine verification program. The firms will undoubtedly learn important lessons about the new turbines. In the process, two more investor-owned utilities, 14 municipal utilities, and a rural electric cooperative will learn what it's like to generate and distribute wind power. That's what EPRI and DOE had in mind when they started the program. 
+4. 


\section{Partnerships between}

governuent and provate indinth

\section{foster the ierelopment}

of invouthe revinobshs:

\section{urbines on the Horizon innovative components, and able to prove 1 megawatt (MW) will crank out electricity in Large, powerful turbines rated as high aller machines will light buildings, pump water, modern utility power plants. Much smater isolated areas of the planet. Some turbines will or charge batteries in some of the most istow tow be ultralight and flexibl
feet above the ground. 
Tomorrow's turbines will be designed according to where they will be used and the local availability of equipment and skilled labor. Where winds are high or turbulent, turbines will have smaller rotors and be built to withstand severe stresses. Where skilled labor is not readily available, turbines will be simple and robust. Wherever they are installed, the next generation of wind turbines will generate $15 \%-30 \%$ more electricity-at a lower cost-than today's machines.

Wind energy is one of the most cost-competitive renewable energy technologies. Even so, windgenerated electricity still costs more than electricity from natural gas or coal plants. However, the wind turbine of the future is expected to close the gap, providing low-cost electricity for homes, businesses, schools, manufacturing plants, and the like. Lowcost turbines will open up a huge market for wind energy in the United States.

\section{COST OF WIND ENEREY}

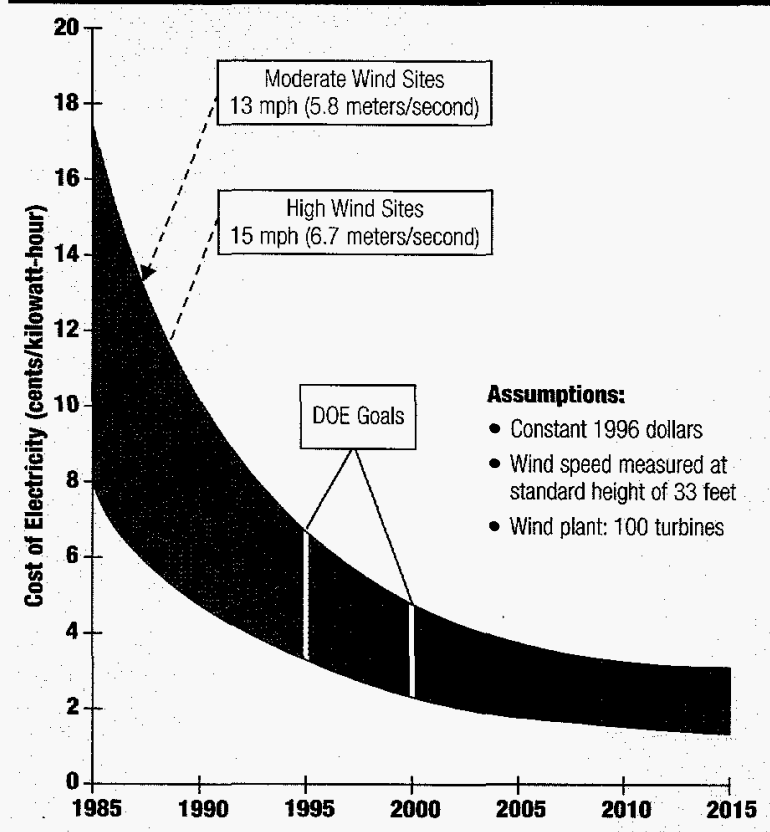

Wind energy is one of the least expensive renewable energy technologies. A new generation of wind turbines will make wind-generated electricity competitive with power from existing natural gas or coal plants.

Cost, however, is not the only benefit wind turbines offer. "Wind energy is an environmental technology," says Randall Swisher, executive director of the American Wind Energy Association. "Wind turbines don't emit acid rain precursors, greenhouse gases, or other air pollutants. We expect growing concern about the environment to drive markets for wind around the world."

Indeed, wind energy is the fastest-growing energy technology in the world. Pressure to develop new

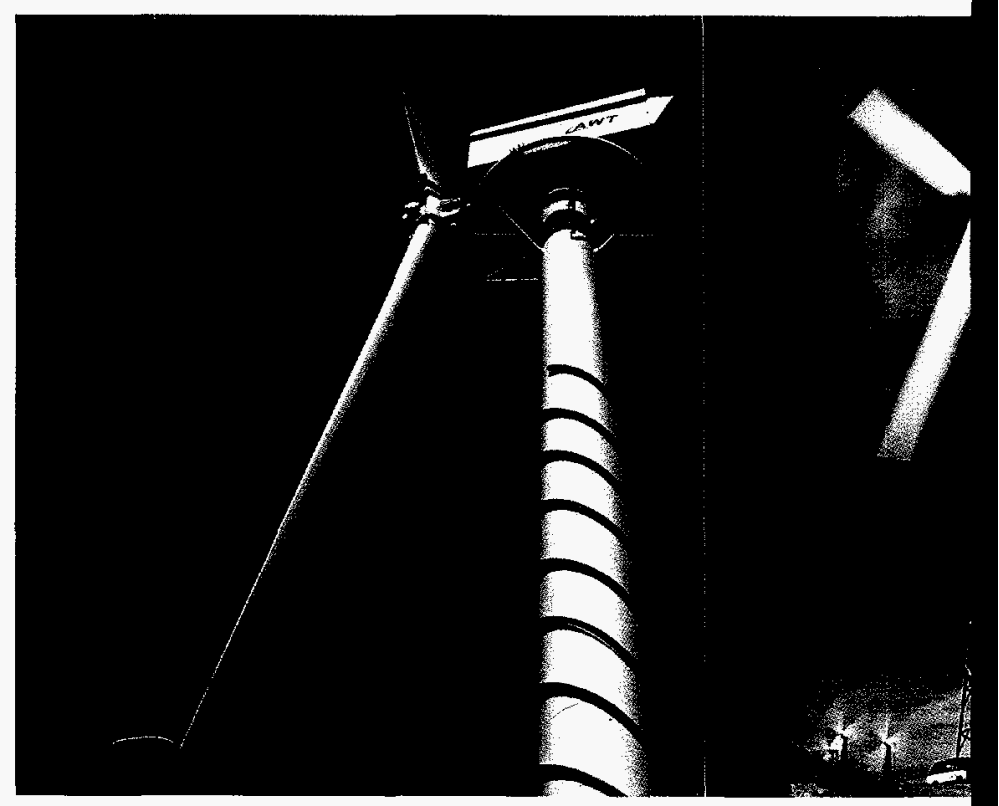

The first turbines created by the U.S. Department of Energy's partnerships with tured by Advanced Wind Turbines, Inc.; the Z-40, manufactured by Zond Sys

technology is being fueled by exploding world wind energy markets that already top $\$ 1.5$ billion a year. The American Wind Energy Association predicts this figure will grow as much as tenfold during the next decade.

By then, designers will have the ability to mix and match innovative components with proven technology to come up with the least expensive, most efficient machine to do a particular job. Whether the job is a small communications relay in Antarctica or a utility wind power plant covering hundreds of acres in the Midwest, wind turbines will provide affordable, clean power in the 21st century for tiny villages and bustling cities alike.

The U.S. Department of Energy (DOE) wants to help U.S. companies capture a sizeable portion of these growing wind markets. In 1992, DOE launched partnerships with U.S. wind companies to rapidly develop innovative, low-cost wind technologies to compete in global energy markets. Although the first turbines created by these partnerships are already on the market, a whole new generation of turbines should arrive by about 2002. Sporting innovative technology, the new turbines will bring the cost of wind energy down as low as $\$ 0.025$ per kilowatt-hour at high wind sites. At this price, substantial numbers of electric power producers are likely to take account of wind's environmental benefits and opt to build wind facilities rather than fossil-fueled power plants. This article describes how DOE's partnerships with industry are lowering the cost of energy from turbines and improving turbine technology for today and the future. 


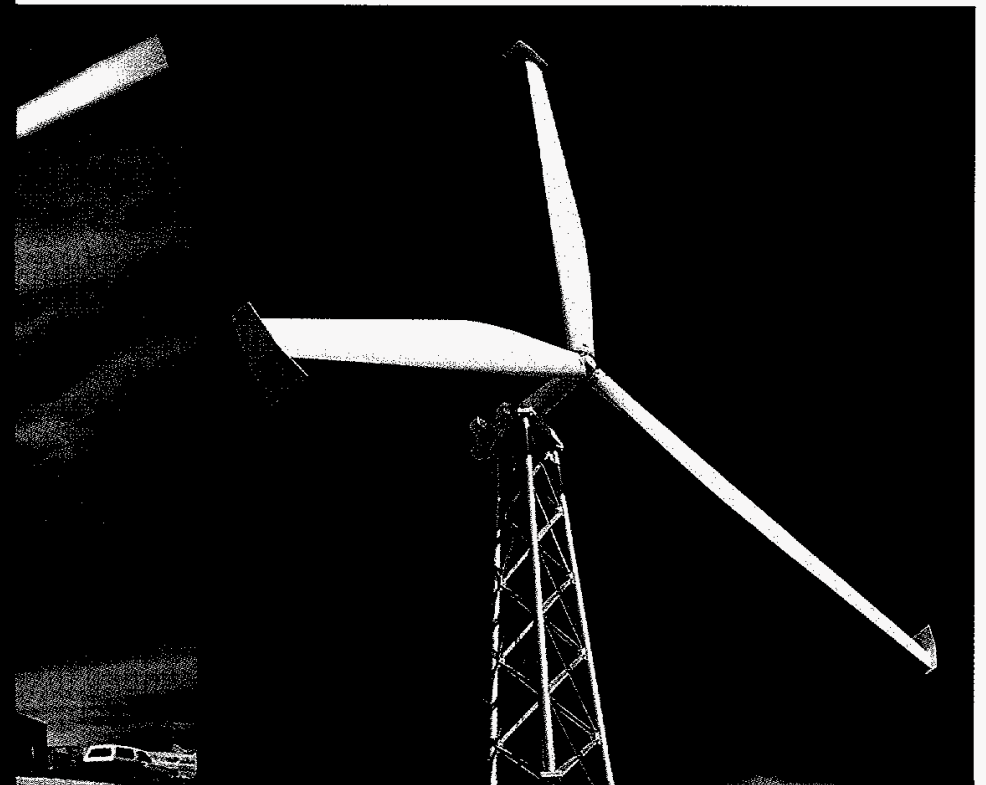

re already on the market. They are (from left to right) the AWT 26, manufacand the AOC 15/50, manufactured by Atlantic Orient Corporation.

\section{IMPROVED TURBINES \\ GENERATE BENEFITS}

The first turbines developed under the DOE program are refined and improved versions of existing machines. All were developed in collaboration with a DOE national laboratory, the National Renewable Energy Laboratory (NREL), in Golden, Colorado. Engineers at NREL's National Wind Technology Center (NWTC), the nation's leading wind research laboratory, worked closely with the industry partners.

Advanced Wind Turbines, Inc.'s AWT-26 and AWT-27. The 275-kilowatt (kW) AWT-26 and AWT-27 wind turbines are on-line in California, Colorado, China, and east-central India. This "downwind" turbine operates facing away from the wind. The AWT turbines have only two blades and a teetered rotor. The teetered rotor rocks back and forth in response to wind gusts, dissipating some of the forces in the wind that can cause wear and tear on the turbine.

Because a teetered rotor can relieve wind stress on the turbine, components such as blades don't have to be as strong and heavy to survive repeated buffeting by the wind. Teetered rotors typically have two blades. Using two rather than three blades represents a large cost savings because blades account for a significant portion of the overall cost of a turbine.

Zond Systems, Inc.'s Z-40. The $550-\mathrm{kW}$ Z- 40 is currently undergoing extensive testing at wind power plants in Vermont and Texas. The three-bladed turbine is a sleek, modern version of the conventional wind turbine that evolved in Europe from the classic Dutch windmill. The "upwind" Z-40 turbines face into the wind while operating. They are strong, heavy, and built to withstand wear and tear from continuous exposure to the wind.

Atlantic Orient Corporation's AOC $\mathbf{1 5 / 5 0}$. The $50-\mathrm{kW}$ AOC $15 / 50$ is a downwind, three-bladed turbine. This smaller turbine was developed for hybrid village power systems. Hybrid power systems, which often include both wind turbines and diesel generators, provide power for villages without access to a central utility grid. The AOC $15 / 50$ is currently being tested at the NWTC, in Denmark, and in northwest Alaska.

\section{INDUSTRY PARTNERSHIPS DEVELOPING CU'TIING-EDGE TECHNOLOGY}

In addition to improving existing turbines, DOE and industry are improving particular turbine components. NREL and another national laboratory, Sandia National Laboratories (Sandia), have worked since 1994 with industry on cost-shared projects to develop the cutting-edge wind turbine components needed to create larger, more cost-effective wind turbines. The partnerships have focussed on expensive turbine components such as towers, rotors, generators, and control systems. The result: tall, inexpensive towers, novel rotors, custom generators, solid-state electronics, and "smart" turbine controls are now in the pipeline for the next generation of wind turbines.

Taller Towers Reach for the Wind. Wind speed generally increases with height above the ground. Taller towers expose turbines to stronger winds, enabling them to produce more electricity. Until now, the value of the extra electricity has been nearly offset by the cost of materials to make the towers bigger, at least for traditional steel lattice or tube towers. However, innovative tower designs are allowing taller towers to be built at reduced cost. Consequently, average tower height should gradually increase from 100 feet to about 230 feet by about 2005.

Innovative Rotors Increase Energy Capture. Rotors are large, heavy, and crucial to capturing energy from the wind. Because improvements in rotor design have a great impact on energy costs, NREL and Sandia have looked into new designs for airfoils; innovative hub attachments that allow rotors to be more flexible; and improved manufacturing processes for blades.

Airfoils specifically designed for turbine blades can greatly enhance turbine performance. Airfoils are the cross-sectional shapes on airplane wings or turbine blades that convert airflow into forces that can lift an airplane or turn a turbine rotor. Since 1984, NREL researchers have created seven "families" of airfoils for turbine blades of specific sizes. The 


\section{COMPUTER SIMULATIONS HELP DESIGNERS BUILD BETTER MACHINES}

The National Renewable Energy Laboratory (NREL) is currently working with Cannon Wind Eagle Corporation to test and refine one of the lightest, most flexible wind turbines ever made: the Cannon Wind Eagle 300/30. The Wind Eagle $300 / 30$ is a downwind, two-bladed turbine that sits on top of a tall, thin, tilt-down tower. Its long, lightweight blades are attached to the rotor hub

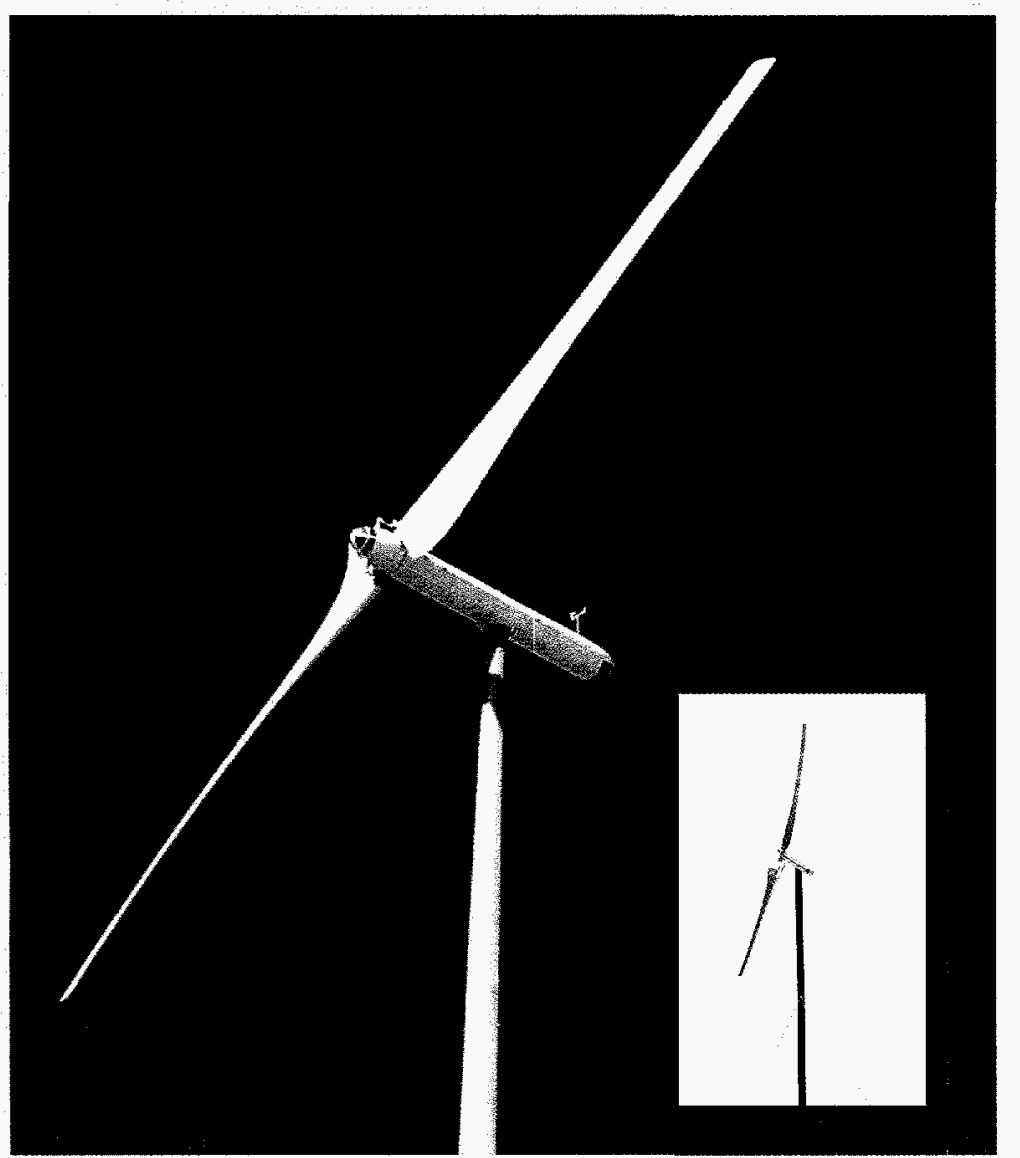

Researchers at the National Wind Techology Center are testing the Cannon Wind Eagle $300 / 30$ and comparing test results witb computer simulations. The simulations will allow design engineers to enbance turbine performance without spending lots of money.

with a flexible crossbar. During high winds, the blades bend downwind in a cone shape. The turbine cover (nacelle) is also free to rotate, to better align the machine with the prevailing winds. These features deflect forces in the wind off the turbine. As a result, this lightweight machine can withstand harsh wind conditions as well as its more massive counterparts. 
be linked together and attached to the low-speed shaft by means of a single hinge. During 1998 , researchers will install the hub on a research turbine, study both strategies, and determine which one works best. Their goal is to prepare for the development of a new class of lightweight, flexible wind turbines whose high-performance rotors will significantly lower the cost of energy production.

Sandia is also striving to lower the cost of turbine rotors by working with industry to improve manufacturing of turbine blades. By improving manufacturing processes, shortening the time it takes to cure the blades, and making other improvements, researchers hope to reduce the blade costs by as much as $25 \%$. Sandia is also working with industry and academia to improve blade-manufacturing processes for fiberglass and plastic blades.

Custom Generators Promise Better Performance. Today, most wind turbines use constant-speed generators to make electricity from the rotational energy produced when the wind turns the turbine rotor. These standard generators are widely available from industry. They are affordable but require costly transmissions and gears to operate. The gears increase the speed of the turbine rotor, which is 60 revolutions per minute ( $\mathrm{rpm}$ ) or less, to $1,800 \mathrm{rpm}$, the rotational speed required to operate a typical generator.

The development of generators that work at low rotational speeds holds promise for better performance at lower cost. Because some generators can operate at the same rotational speeds as the turbine rotor, the expensive gearbox can be eliminated. Designing the generators is a major technical challenge, however. To work, low-speed generators require custom-made, high-efficiency, solid-state electronic converters, called power electronic converters, to generate 60 -cycle alternating current and allow the generator to operate at variable speeds.

NREL researchers believe custom-made, lowspeed generators with power electronics and variable-speed operation will be able to produce about $10 \%$ more electricity than their constantspeed counterparts. Because they can respond to changes in the wind, variable-speed generators can keep the turbine operating at maximum efficiency. Plus, they are quieter and reduce wear and tear on the turbine. In a constant-speed machine, rotor speed must be held steady and cannot increase once the turbine is producing maximum power. In a variable-speed machine, the rotor can spin faster in response to increases in wind speed, thereby using more of the power in the wind to generate electricity.

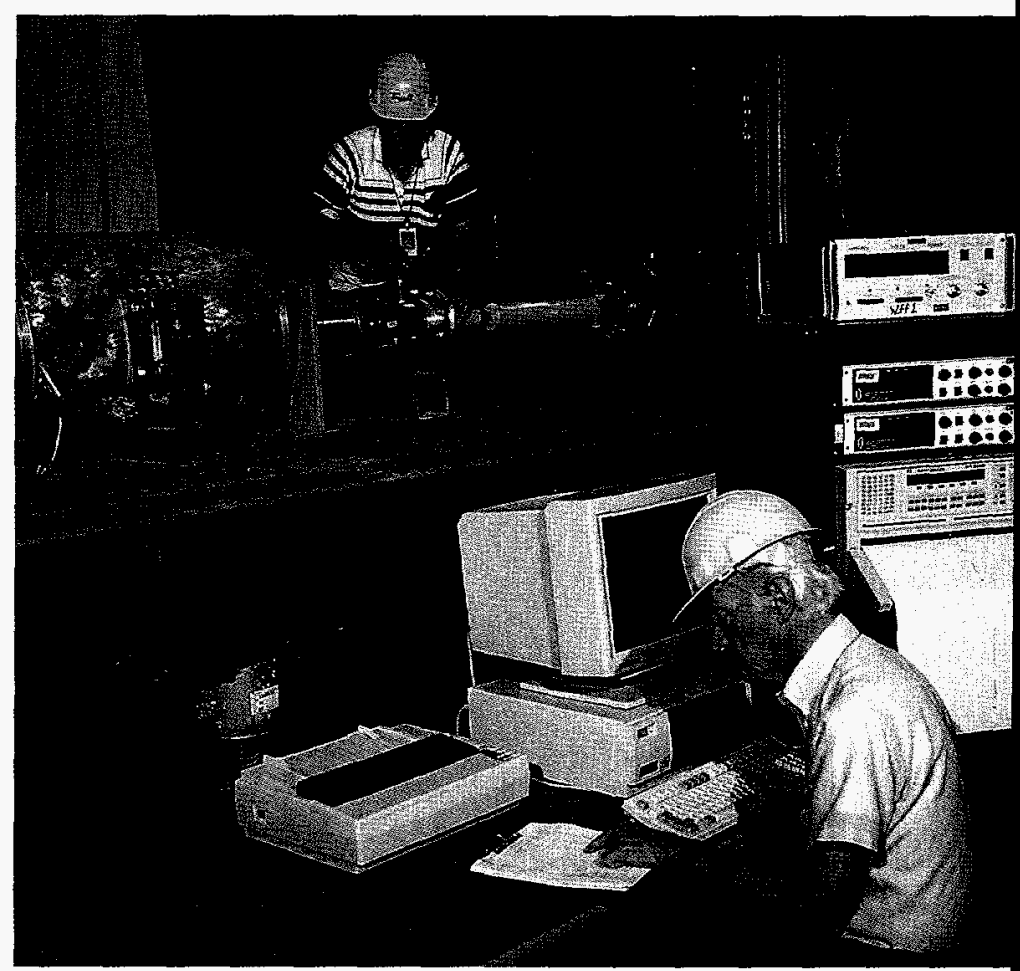

Researchers at the National Wind Technology Center test an experimental variable-speed generator and power electronic converter with a dynamometer, which mimics a rotating turbine. The center will add a 1.5-megawatt dynamometer for testing utility turbine generators.

Variable-speed generators should work well with both standard, three-bladed machines and two-bladed, flexible turbines. Designing custom generators and power electronics that both work efficiently at low wind speeds is essential, however. Otherwise, poor performance at low wind speeds will offset some of the gains in efficiency at higher wind speeds.

In work done under contract with NREL, the University of Colorado (CU), Northern Power Systems, Inc., and Electronic Power Conditioning, Inc. (EPC), are developing innovative low-speed generation systems. The new systems are expected to reduce turbine wear, operate efficiently, produce high-quality power, and permit quieter turbine operation, particularly at low wind speeds.

CU has developed a permanent-magnet, directdrive generator. In a direct-drive system, the generator is directly linked to the rotor, eliminating the need for an expensive transmission and gears. NREL is testing the CU generator/power electronic converter system on a research turbine at the NWTC. Engineers are investigating ways to maximize the performance of variable-speed power systems. As part of the project, they are testing turbine control software designed to optimize energy production and minimize stresses on the turbine. 
Northern Power Systems is working on a low-speed generator similar to the ones used in hydro-electric facilities. When it is built, the company plans to install the new generator on a $100-\mathrm{kW}$ turbine designed for operation in frigid climates. EPC developed a unique variable-speed generation system with a power electronic converter half the normal size. Consequently, the system is less expensive.

Designing a Brain for Tomorrow's Wind Turbines. In the past, turbine controls were used to solve particular problems: to slow or stop the rotor, to prevent wind gusts from suddenly producing too much power, to prevent the turbine from vibrating during operation, to mitigate damage from turbulent winds, and so on.

A better way to control a wind turbine is via an electronic brain, or smart controller, which can optimize every aspect of turbine operation. Smart controllers use miniature computers, called microprocessors, to continuously evaluate wind conditions and turbine operation at any given moment. The controller then adjusts turbine operation to maximize the amount of power it generates, to protect the machine from excessive wear and tear, and to ensure maximum service life, low energy costs, and safe operation. Such a controller will ensure the maximum benefit from using light, flexible rotors and custom generators.

Engineers at NREL and Sandia are working with university researchers to design a computerized control system for wind turbines. Starting with a computer model that includes control strategies to solve typical problems, they are programming it to systematically evaluate a particular strategy's costs and benefits under a variety of conditions. The smart control system will assess how a particular device such as a tip brake affects the entire wind turbine. It will decide whether using it makes more sense than another method for slowing the rotor.

In the future, system control specialists will work on designing new turbines from the beginning. Understanding how a wind turbine works, they will be able to design smart control systems as an integral feature of the next generation of utility wind turbines.

Control Systems Improve Plant Efficiency. Computerized control systems can also help wind power plants run more efficiently. NREL's partner Second Wind Inc. recently completed a sophisticated wind power plant control system. The system can monitor each turbine's power output as well as current wind conditions. Power plant operators can use this information to adjust the operation of individual turbines to maximize power output or minimize wear and tear on the machine. A supervisory computer also allows operators to see the entire power plant at one time by displaying a map of the turbines, meteorological towers, and substations. DOE is using Second Wind's power plant control system to monitor: turbine performance in new projects being developed under the Utility Wind Turbine Verification Program (see page 2 for more about the program).

\section{NEXT-GENERATION UTILITY \\ WIND TURBINES ON TAP FOR THE 21ST CENTURY}

The new towers, rotors, generators, and controls built through $\mathrm{DOE} /$ industry partnerships will improve the performance of tomorrow's turbines. In 1994, DOE announced a $\$ 40$ million program to develop a new generation of innovative utility wind turbines for the next century's marketplace. The cost-effective new utility turbines will expand markets for U.S. companies in the United States and in Europe, where competition for new wind projects is driving costs down.

Eight industry teams created concepts for new utility wind turbines rated as high as 1 MW. In 1996, NREL selected two of the firms, Ziond Systems, Inc., a subsidiary of Enron Wind Corporation, and The Wind Turbine Company, to bring their concepts into reality. Both firms will incorporate new technology developed by NREL and its industry partners into their new machines.

Zond is developing the Z-56, an upwind, variable-speed turbine rated at $1 \mathrm{MW}$. The threebladed turbine will be the largest, most sophisticated turbine of its kind made by an American company. It will include a smart controller, NREL airfoils, and a custom-made, variable-speed generator and power-electronic converter.

Ken Karas, chairman and chief executive officer of Enron Wind, is excited about participating in the next-generation turbine development effort. "We are pleased and proud to be part of this cooperative research effort," he said. "We have high expectations and look forward to advancing the cost-effective utilization of clean wind energy."

The Wind Turbine Company is designing the WTC 1000 , a dual-speed machine rated at $1 \mathrm{MW}$. The lightweight turbine will have multiple generators and a flapping rotor similar to the one used on the first utility wind turbine built in the United States, the Smith-Putnam turbine erected on Grandpa's Knob in Vermont in 1943. The turbine's two blades will attach to the rotor hub with hinges, which allow the blades to flap in and out of the plane of rotation depending on the forces impacting the rotor during high winds. The turbine will sit atop a 328-foot tower. The thin tubular tower will have an elevator inside it to carry maintenance workers up to the turbine. 




The Wind Turbine Company's WTC 1000, left, and Zond Systems, Inc.'s Z-56, right, will crank out as mucb as 1 megawatt of electricity in utility wind power plants.

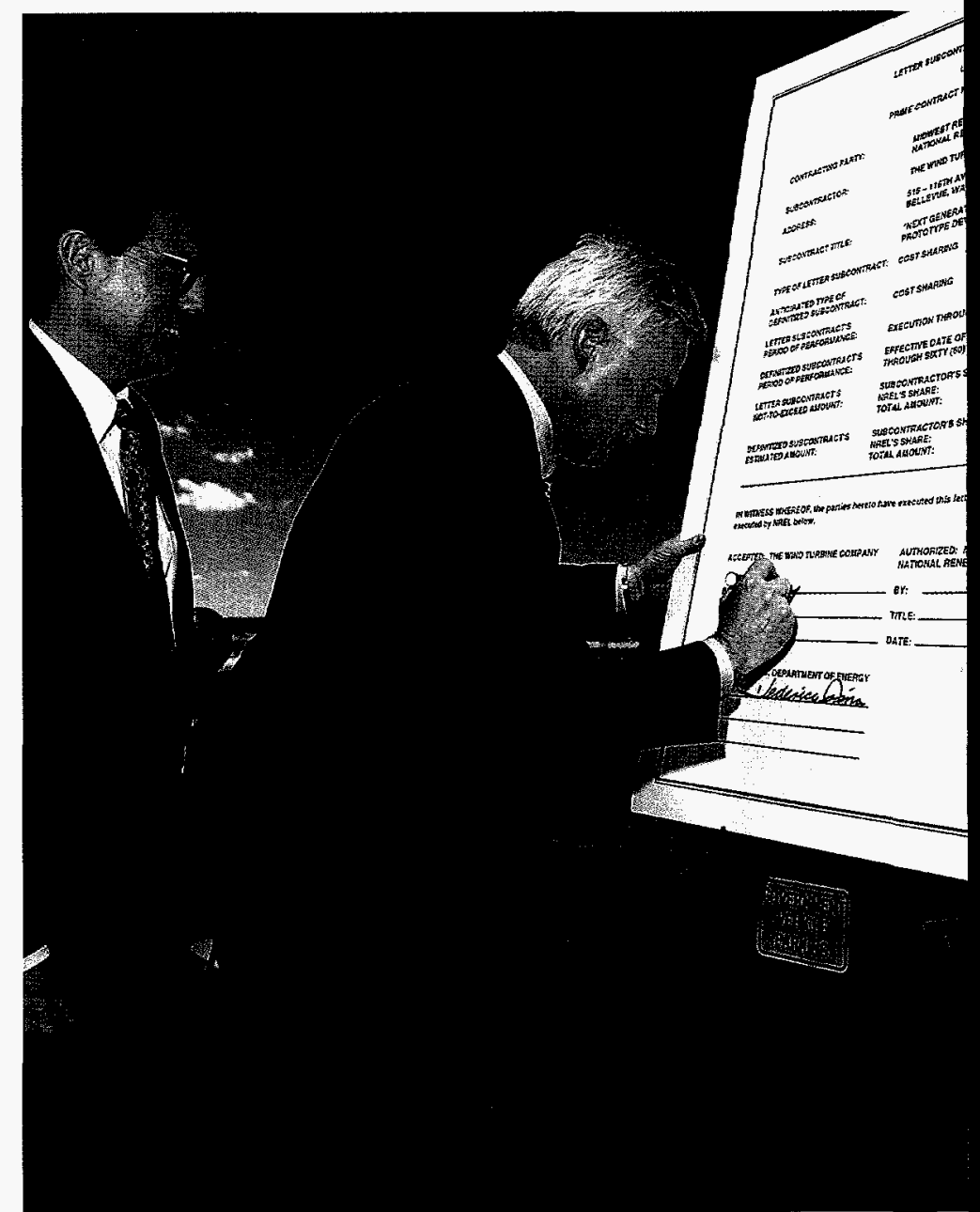

As U.S. Secretary of Energy Federico Peña looks on, The Wind Turbine Company President Larry Miles signs a \$20 million subcontract with the National Renewable Energy Laboratory. The company will design, build, and test a next-generation utility wind turbine by 2002.

The \$20 million, Next-Generation Turbine Program contracts are the largest in the history of the federal wind energy program. U.S. Secretary of Energy Federico Peña was guest of honor at the formal signing of the contracts on June 20, 1997, at the NWTC. The center is located at the foot of the Rocky Mountains in Golden, Colorado, just west of Denver.

"These partnerships with the wind energy industry will help speed advanced clean energy technology to the marketplace," Secretary Peña said at the contract signing. "When we build partnerships with industry, we all benefit. It is important for the wind industry to be in a position to take advantage of domestic and international markets that are expected to grow rapidly over the coming decade."

Utilities have about three to four years to wait until Zond and The Wind Turbine Company introduce their next-generation utility wind turbines. 


\section{ADVANCED SMALL WIND TURBINE} PROJECT TARGETS VILLAGE POWER

Today's $\$ 1.5$ billion a year world wind energy market is fed not only by utility wind turbines, but also by so-called small wind turbines with rated power up to $40 \mathrm{~kW}$. The Small Wind Turbine Project was started in 1995 to support the development of advanced turbines to be used singly or in clusters in remote or rural areas. The small turbines will provide electricity where none is available from conventional sources or where fuel costs are prohibitively high. (Currently, more than 2 billion people around the globe lack electricity; the number is growing.) Small turbines can offer cheaper electricity than that from diesel generators.

The small turbines will use cutting-edge technology-towers, rotors, generators, and controls-developed for utility machines. New technology will make small turbines more reliable and cost effective as well as easier to transport and install than today's machines. The turbines may be tailored for specific regions such as the desert, the seacoast, or cold, wet climates.

One or more of the small turbines can power a cabin, telecommunications relay, business, school, community center, clinic, or an entire village. Farmers can use small turbines to power their homes and other buildings or pump water for livestock or irrigation. In some cases, utilities may erect a cluster of turbines at the end of a distribution line in lieu of building a power plant or extending a transmission line.

In 1997, NREL awarded contracts to four industry partners to develop advanced small wind turbines: Bergey Windpower Company, WindLite Corporation, World Power Technologies, and Cannon Wind Eagle Corporation. Bergey Windpower Company, WindLite Corporation, and World Power Technologies will develop enhanced versions of three-bladed, upwind turbines.

Bergey Windpower will build a $40-\mathrm{kW}$, variablespeed turbine for use in village power systems. Different-sized rotors will be available so the turbine can be used in a variety of locations. The turbine will sit atop a 180-foot tower to take advantage of higher wind speeds aloft.

WindLite is designing an 8-kW machine with a direct-drive, variable-speed generator. The turbine comes with a 110-foot tilt-up tower. Applications include battery charging, communications, lighting, and water pumping. The turbine will be made of weather- and corrosion-resistant materials to allow it to operate in cold, wet climates or near the ocean.

World Power will construct a $16-\mathrm{kW}$, variablespeed turbine to charge batteries for clusters of homes, large farms, or small businesses. The turbine can be used with solar electric systems or diesel generators. It can also be tied into a utility grid. The turbine will include several innovative technologies, including a permanent-magnet generator. It will sit atop an 80-foot, tilt-up tower.

Cannon Wind Eagle Corporation will build a scaled-down version of the Wind Eagle 300/30 machine. The new Wind Eagle WE-14 will include the very latest in lightweight, flexible turbine design. The $30-\mathrm{kW}$ Wind Eagle WE-14 will be a two-bladed, downwind machine operating at constant speed. The turbine is attached to the tower with gimbals, which allow it to rotate freely on the 120-foot, tilt-down tower. Target markets include village power, ranching, agribusiness, and remote industrial sites.

The advanced small wind turbines will hit the marketplace around the turn of the century. Together with a new generation of utility turbines, they will offer a range of options for generating lowcost electricity from the wind and will help U.S. firms compete successfully in global wind markets.

From small remote villages to bustling international cities, wind energy can meet the need for electricity around the globe without harming the planet. DOE/industry partnerships promise to provide the technology to make clean, lowcost electricity a reality. 


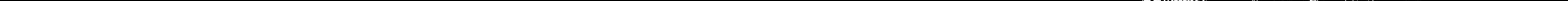







Alaska to Harness Arctí

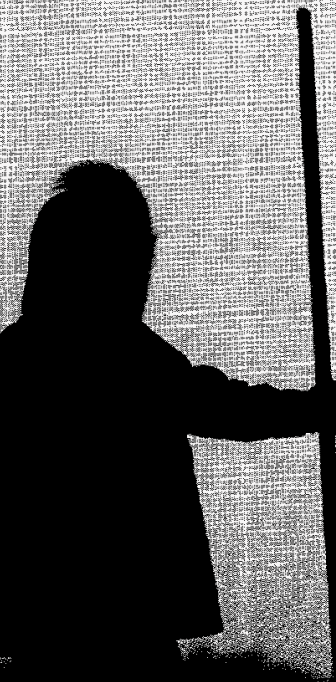




\section{Ninds for Village Power}

Villagers pioneering use of wind energy to save on costly diesel fuel.

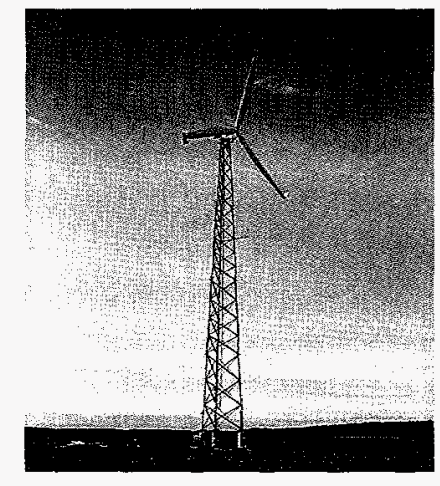

THREE NEW 50-KILOWATT ( $\mathrm{kW}$ ) AOC 15/50 WIND TURBINES ROSE FROM THE VAST expanse of the Arctic tundra during the summer of 1997. During the cold, dark winter, the lonely sentinels harnessed piercing winds to generate electricity for nearby Kotzebue, Alaska's largest Eskimo community north of the Arctic Circle. Brad Reeve, general manager of Kotzebue Electric Association, worked for more than five years to bring the turbines to the community of 3,500 residents. He is determined to show that wind energy can bring affordable electricity and much-needed jobs to the rural inhabitants of northwest Alaska.

"I began thinking seriously about wind in 1992," Reeve says. "I realized our utility could make a real contribution to evaluating renewable technologies. My original idea was to find a good wind turbine and show that it could perform well in the harsh Arctic environment." Five years later, Kotzebue began testing the AOC $15 / 50$ turbines, which have a total capacity of $150 \mathrm{~kW}$.

In the meantime, the small village of Wales agreed to install a new village hybrid power system that uses both diesel generators and wind turbines. Because it uses more wind generation than similar hybrid power systems, the project poses a technical challenge but has the potential to save large amounts of diesel fuel. Led by Kotzebue Electric, the project is being supported by National Renewable Energy Laboratory's (NREL's) National Wind Technology Center, the U.S. Environmental Protection Agency, the Alaska Science and Technology Foundation, and the State of Alaska.

Kotzebue and wales are two of more than 200 Alaskan villages without roads connecting them to the rest of the state or access to an electric grid.
Kotzebue is located on the Baldwin Peninsula where it extends into Kotzebue Sound off the Chukchi Sea. In the Inupiat Eskimo language, the town's name is Kikiktheruk, which means "place almost an island." Wales is located about 75 miles southwest of Kotzebue on Cape Prince of Wales, at the western tip of the Seward Peninsula.

Like other villages in northwest Alaska, Kotzebue and Wales import diesel fuel to make electricity. It is very expensive to transport diesel fuel by barge for use in a village power system. Barge travel is only possible during the summer when ice melts and sea channels are open.

Remote villages in Alaska must have large storage facilities for diesel fuel. Many storage tanks are more than 20 years old and need replacement.

Rural electricity is expensive. Reeve says that without state energy assistance (to the tune of nearly $\$ 17$ million a year), Kotzebue residents would pay $\$ 0.20 /$ kilowatt-hour $(\mathrm{kWh})$ for electricity rather than the $\$ 0.12 / \mathrm{kWh}$ they currently pay. In smaller, more remote villages, unsubsidized electrical costs would run as high as $\$ 0.60 / \mathrm{kWh}$. 


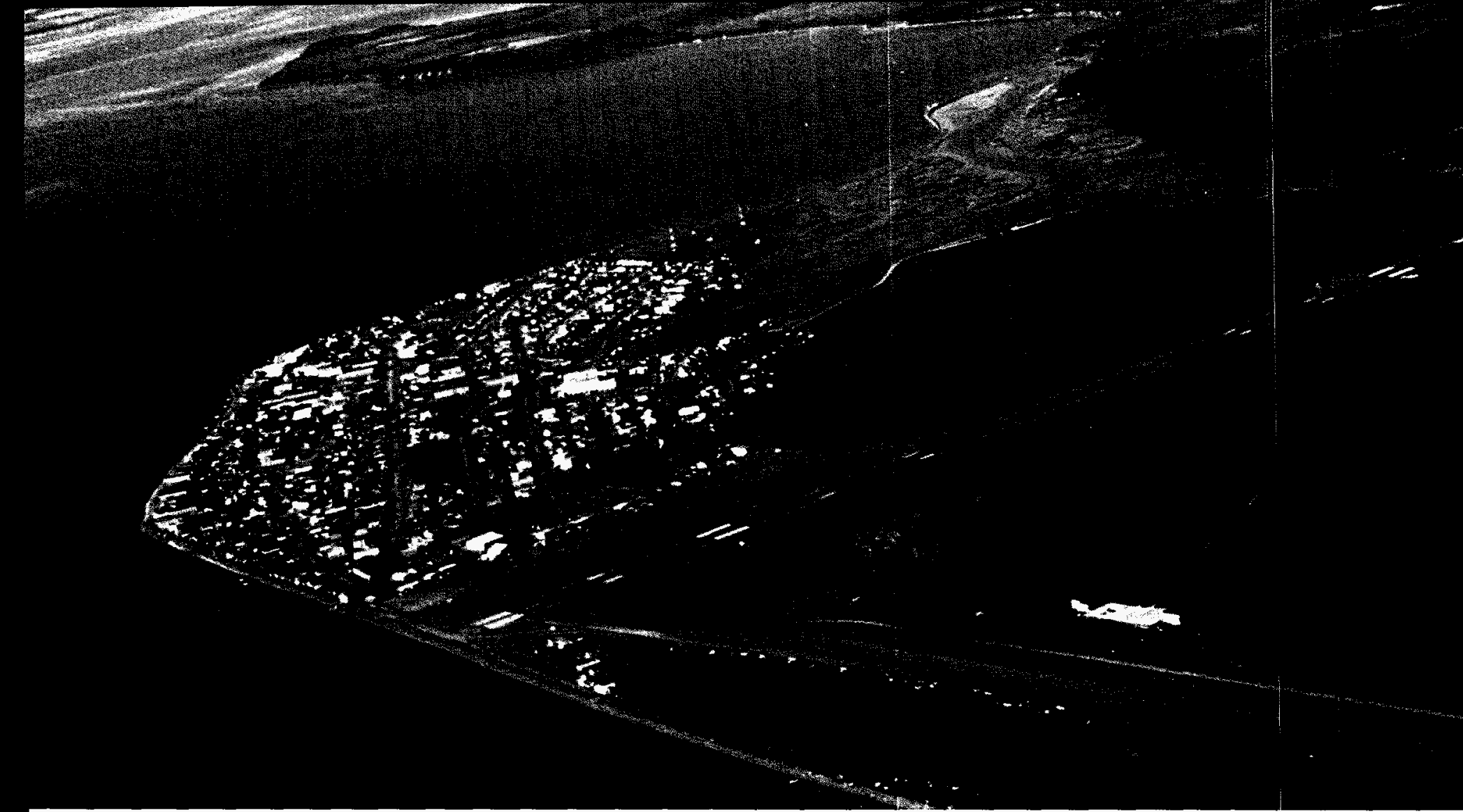

With 3,500 residents, Kotzebue is the largest Eskimo village north of the Arctic Circle. In the Inupiat Eskimo language, the town's name means "place almost an island."

"The costs of transporting diesel fuel this far north are very high," explains Reeve. "Power production from diesel fuel is also very expensive. That's why we're looking for alternative methods for making electricity."

Since the mid-1980s, Alaska's Power Cost Equalization Program has helped buy down the cost of rural electricity. The program supports diesel power generation in 175 villages, many of which were without electricity prior to 1985 . Since then, rural inhabitants have become reliant on electricity for household appliances, lighting, water, and sewer systems.

Oil revenues to the state from North Slope oil are rapidly declining, however. Alaska's oil fields are becoming depleted, which means less money is flowing into state coffers. Brad Reeve worries that the power cost equalization program could disappear within a few years, forcing Kotzebue residents to pay full cost for their electricity-or do without.

"I'm very concerned about the cost of energy," Reeve says. Kotzebue's economy depends on government services and seasonal jobs such as fishing and reindeer herding. Reeve says there's no way Kotzebue and hundreds of other, smaller villages can pay twice as much for electricity and still hope to create jobs that would allow their residents to get off welfare. Federal welfare reform, together with the end of state energy subsidies, could put Alaska's rural inhabitants between the proverbial rock and a hard place.
"We've got to find another way to reduce the cost of power," Reeve says. "That's why we've pushed so hard to get a wind power project here."

During the past five years, Reeve has made numerous trips to seek funding for wind turbines to Washington, D.C., and to NREL, in Golden, Colorado. He has worked closely with state officials from Alaska's Department of Community and Regional Affairs. He wants Kotzebue Electric Association to play a key role in developing Alaska's indigenous wind energy resources, thereby reducing reliance on costly diesel fuel.

Reeve would like to see Kotzebue become a center of excellence for U.S.-built wind-diesel village power systems. He wants to educate other communities about the benefits of using new technology. Under Kotzebue Electric Association's mentorship, dozens of other coastal villages would install wind-diesel systems.

"Rural wind development is going to grow out of Kotzebue," explains Dennis Meiners, a development specialist with Alaska's Department of Community and Regional Affairs. "It's going to be a wind development hub. There's going to be a training facility there. The turbines are already up, and they're busy working out technology issues."

The Kotzebue wind project will prove whether wind technology can perform reliably in Alaska and cut costs, according to Meiners. Once that happens, a large market for wind systems is l:kely to develop. 


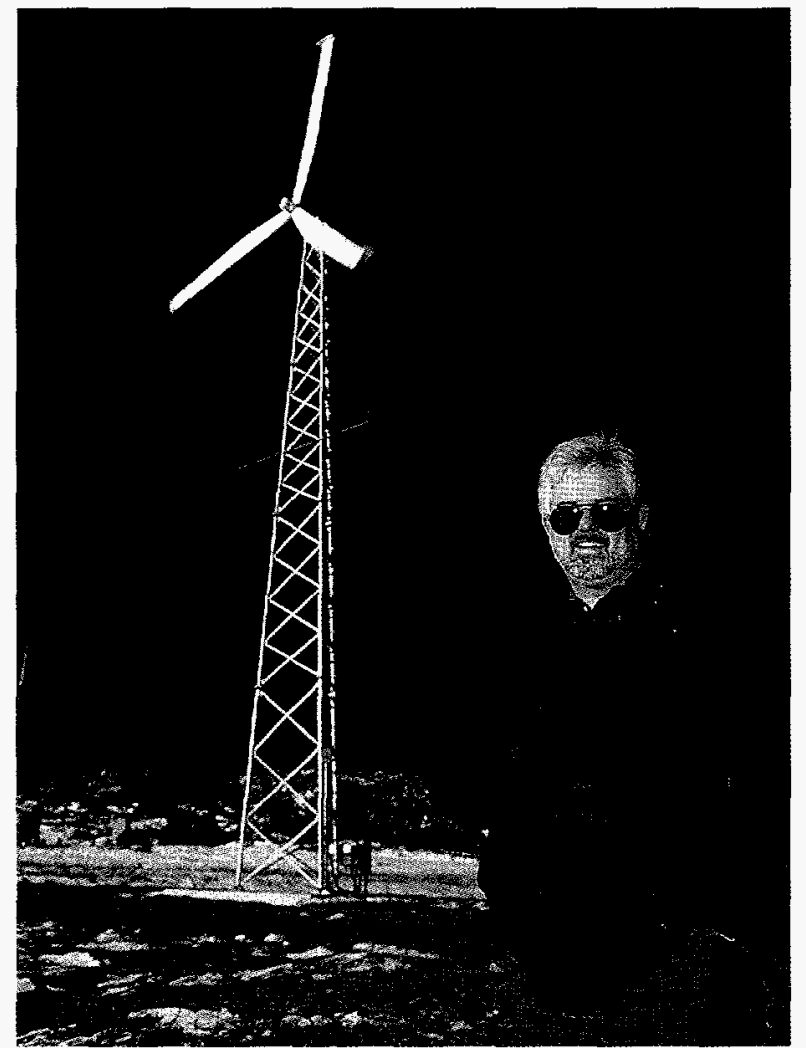

Brad Reeve stands by an AOC 15/50 turbine at the National Wind Technology Center. Reeve visited Colorado in November 1997 to discuss Wales's new hybrid village power system, which will use AOC 15/50 turbines.

"From Kotzebue, wind will work its way down the coast, heading south," Meiners says. "By next summer [1998], the State of Alaska will be looking at four to ten new sites, conducting wind resource assessments, and studying the impact of wind on local economies."

Meiners bases his optimism on an assessment he did in 1995, which found almost 90 villages in Alaska with enough wind to make wind energy development viable.

"I sat down with [the U.S. Department of Energy's Wind Energy Resource Atlas of the United States] to see which communities had enough wind to be worth investigating," he explains. "I was amazed at how many locations looked as if they had great resources. This whole region of the state has no trees. It's at sea level. The wind just blows in off the ocean across the land for hundreds of miles."

Meiners found so much wind, in fact, that he was certain the resource would not limit wind development. He shifted his attention to looking at economic issues and locating turbines rugged enough to stand up to Alaska's winters. Meiners didn't want to repeat mistakes made in the 1980s.

"In the mid-1980s, the state participated in about
140 small wind projects," he says. "The trouble was, most of them never worked. And, when something went wrong, the manufacturers just walked away. There were no maintenance programs, no customer support programs, nothing."

Meiners concluded the most important thing he could do to get wind power up and running in Alaska was to find a reliable cold-weather turbine. Kotzebue Electric's Reeve agreed.

"During the early 1980s, while I was managing the public radio station in Kotzebue, someone brought in a wind turbine to generate electricity for the city manager's quarters," he recalls. "They erected another one at Chukchi Community College. Neither one worked well.

"One night when I was taking a friend home on a snowmobile during a blizzard, we heard what sounded like a DC-3 coming down over our heads. I knew it had to be the wind turbine. The next day, the blades were gone. We never found them. They just disintegrated."

When Reeve left the radio station in 1988 to become general manager of Kotzebue Electric, he decided there must be a better way to implement wind energy.

"The more I thought about it, the more I liked the idea of alternative energy, especially for communities like ours where fuel transport costs are high," he says. "But, I realized that you need to get utilities involved with wind projects. We're in the business of generating electricity, so we know we have to schedule maintenance to keep equipment working."

Within a few years, Reeve was looking for a turbine.

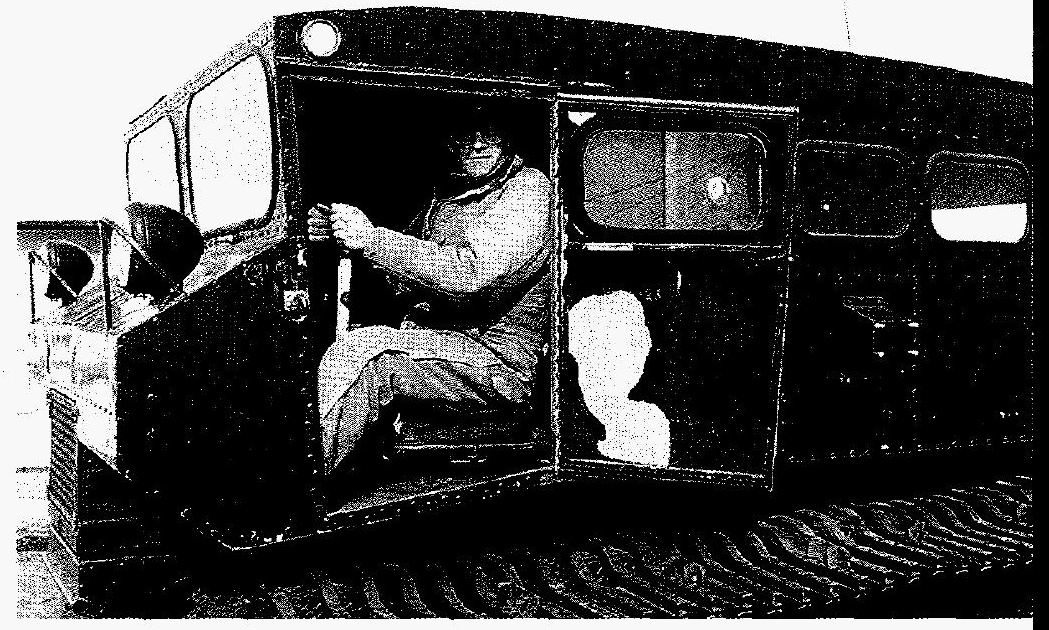

Dennis Meiners of Alaska's Department of Community and Regional Affairs drives out to inspect the Kotzebue wind project site in July 1997. He's driving a special all-terrain vebicle to cross the tundra from the end of the road to the site. 


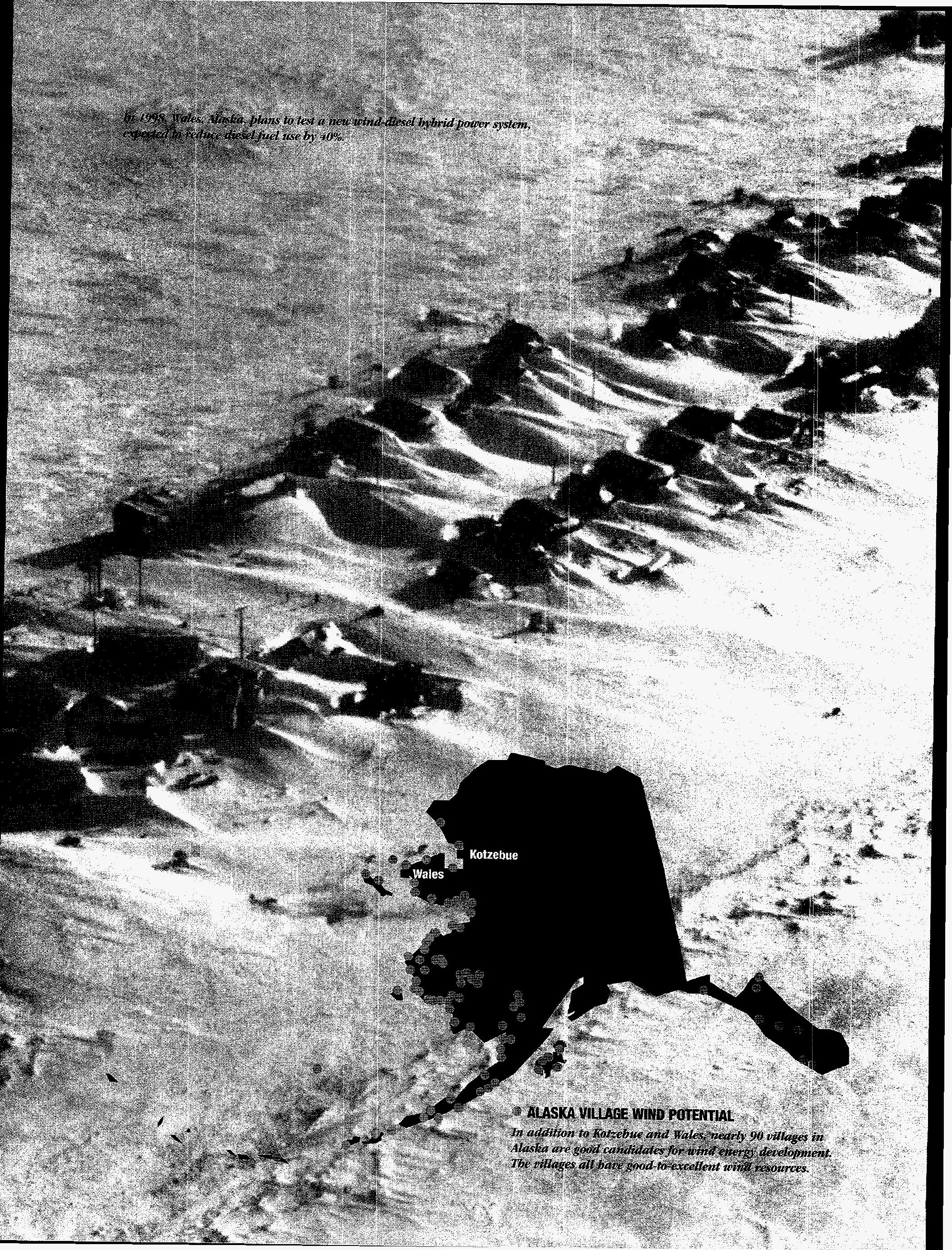


"I looked a long time for a turbine that could work in the cold," he recalls. "At first, I couldn't find any American equipment designed for cold weather. Even when I started looking at the world market, I couldn't find anything I was comfortable with."

Things changed when Reeve joined the Utility Wind Interest Group (UWIG) in 1993. A nonprofit corporation, UWIG was founded with support from both the U.S. Department of Energy (DOE) and the Electric Power Research Institute. The group provides its utility members with information about wind power, discussion forums, and technical support.

"UWIG was a real learning experience," Reeve says. "We had honest discussions about lots of technical issues. I heard about the AOC 15/50 turbine, which [Vermont's] Atlantic Orient Corporation had developed for colder areas." Reeve especially liked the idea of supporting a small American company's efforts to commercialize new technology.

In 1995, Reeve secured a grant from the State of Alaska for $\$ 250,000$, convinced his board of direc- tors to earmark another $\$ 250,000$ for wind development, and ordered three turbines. Due to manufacturing delays, the turbines were not installed until 1997. By then, additional funding from DOE and NREL allowed the utility to order seven more AOC 15/50 turbines for installation in 1998. Reeve's vision of a wind technology project at Kotzebue was on its way to becoming a reality.

The use of wind generation is spreading to other communities. Tiny Wales (with a population of 165) decided to test a wind-diesel hybrid power system predicted to reduce diesel fuel use by $40 \%$. The State of Alaska's Meiners believes the Wales project is critical for wind energy development in Alaska.

"If we expect to make wind valuable to our rural communities, then we've got to take lots of wind and displace lots of diesel fuel," he says. "Diesel generation isn't going to go away. It's reliable, and it does the job. The problem is, it's expensive and it's messy." Meiners wants to integrate as much wind as possible into existing diesel generation systems.

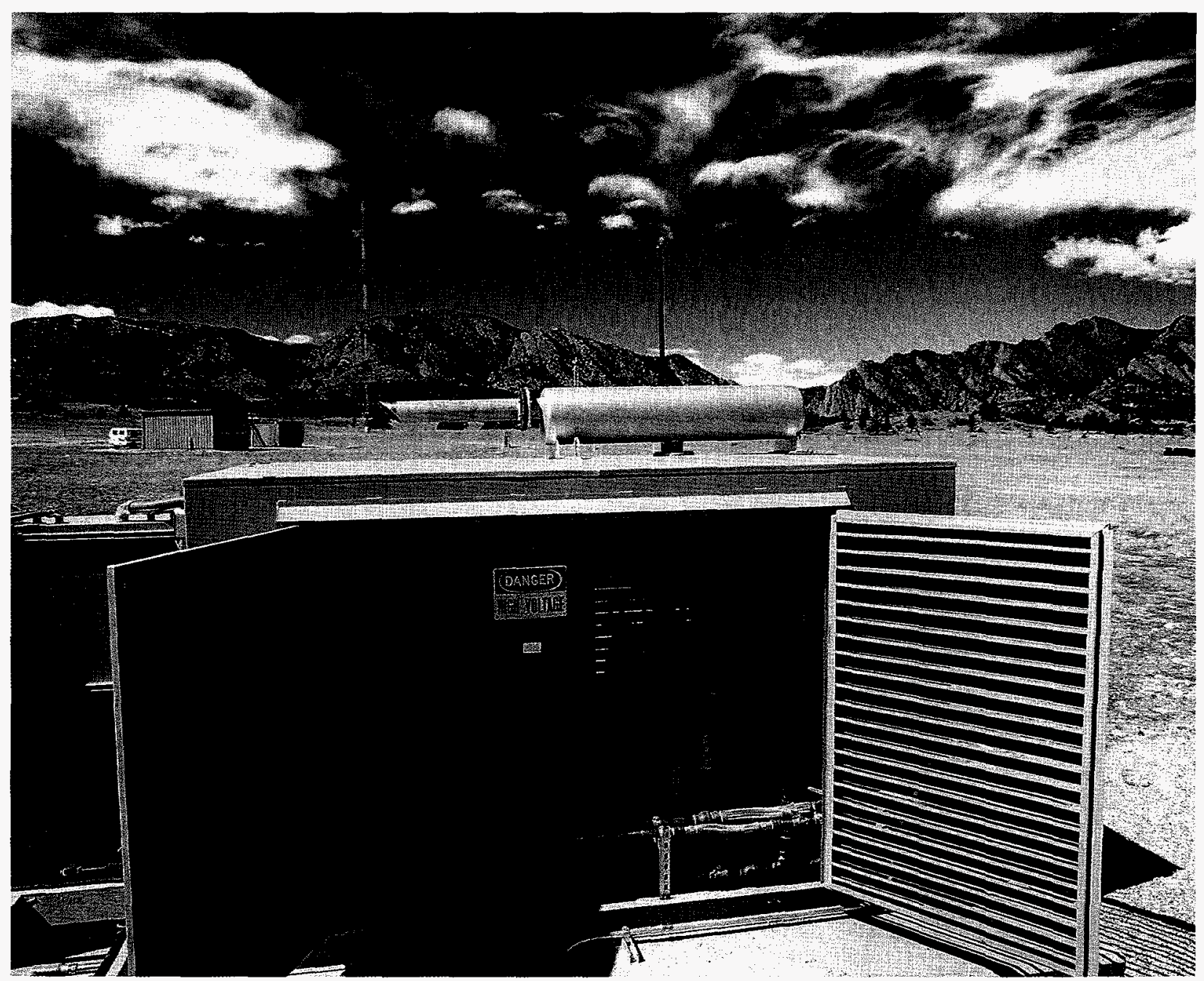

This diesel generator at the National Wind Technology Center is similar to those used in Kotzebue and other Alaskan villages. 


\section{TECHNOLOGY Key to Adoption of Wind Energy in Alaska}

The wind oroject at Kotzebue and the hybrid power systen in Wates are critical tests for vind technelogies in Alaska. The extreme weather conditions in nothwest Alaska inderscore the need for reliable power, which desel generators aready sup. by Wind systems nust perfornisstas rel. ably before firal communities will be wiling to nvest in them:

kotzebue Electric wil instal seven AOC $15 / 50$ wind Uurbires in 1998 , bring ing the total number of turbines there to ten the 50 kfowat (KW) turbines nere devetoped by Allantic Orient Corporation as Bart of the IS Departnent of Energy's Wind Tubine Development Program. The turbines have trree blades the blades incorporate air folls developed by enginers at the national Renewable Energy. Laboratory (MREL) to eficlentlytamess the winds tor generating electricity. The tir bines: sil atop 80 - foot steet lattice tovers. The A0C 15 .50 turbine is typically used with vilage power systems sueh as those in Wales and Kotzebue:

Dung the next tew years, the A20 15.50 wil underge extensive testing at Kotzebue The lesting wit deterine the type of namtenance the turine need to work welt in the Arctic enviremights With winiter whd chill factors as love as

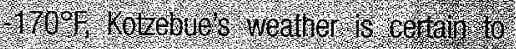
provide a gnveing fest of the luitbine:

The AOC $15 / 50$ turbines have infova? tive roundations nade of steet proses designed to protect tho theria and its

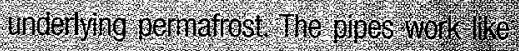

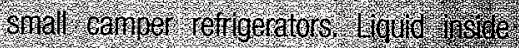
then alternately traporates and: endenses: keeping the ground cool by ranstem ing hea to the sulace via the pipes. During the sarn. ner, the ninitrefrigerators cool the loving a tions enough to keep the tind a a reund them frozen:

The foumations are expensive, rovyry For nis reason. Winy personnet are desigh

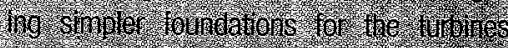
arving in 1968 y he hew touncatens wil

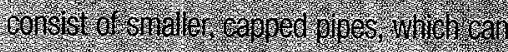
be filted with a refigerant it neeessary.

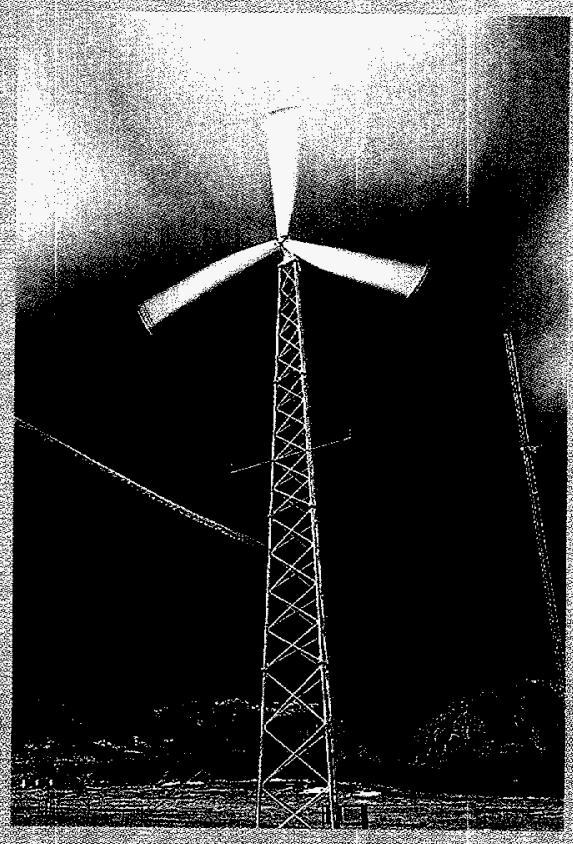

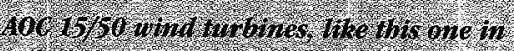

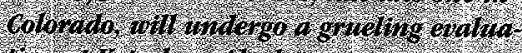

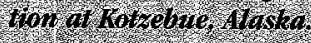

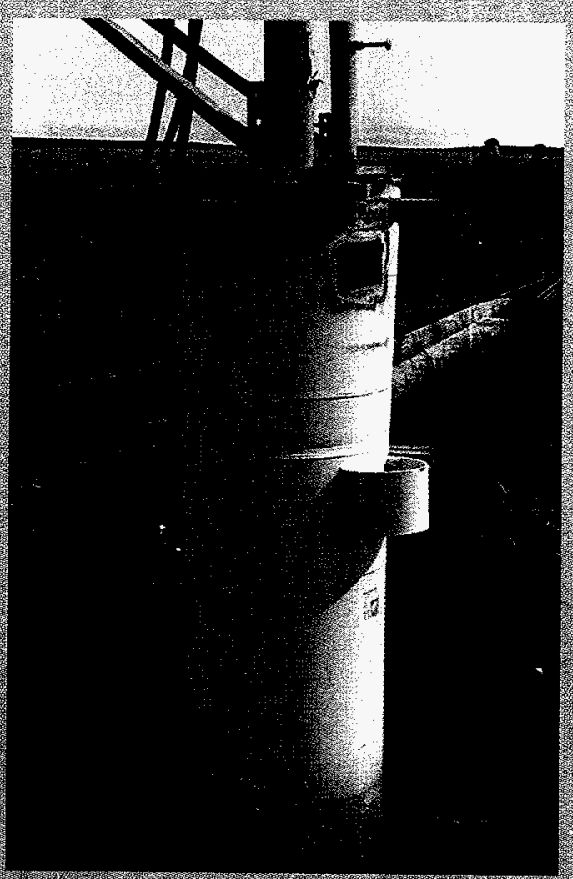

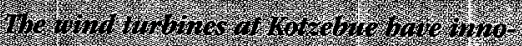

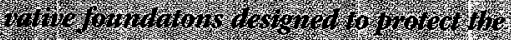

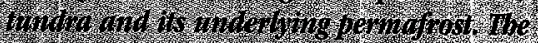

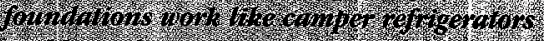

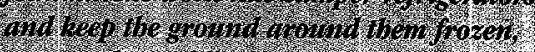

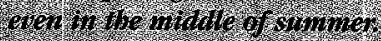

Kotzebue Electric plans to erect more wind machines by 2000 . The utility may purchase other new US turbine models such as the North Wind 100 or the AWT 26

The North Wind 100 , also knawh as the Polar turbine, is currently under devetop. ment by Northern Power Systerns The 100-W Polar turbine is being tailored for operation in frigid envionments subh as those found in nom thern Alaska, Siberita, and Antarctica. Its development is sponsored by NREL the National Science Feundation, and the National Aeronautics and Space Administration (NASA) NASA wats the turbine tested in earth's harshest enviranments to deternine whether It bould one day he ised on Mars to power ife supeor systems

The Polar turbine includes: an in hovictive low speed alternator linked to the tw ibines

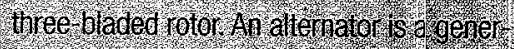
ator hat makes alternating ecrent the direct dive aternater elininates tre need tor gears, which aro expensive eon in inents of nany turbines.

The Polar tuibine comes with a d 70 toot tubular steet tower this bind al thewer

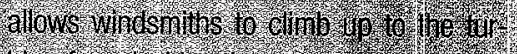
bine from inside where t tey are or trected from the wind The tirbine cover (nabelte) is

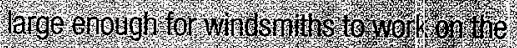

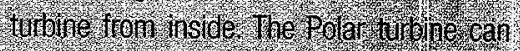

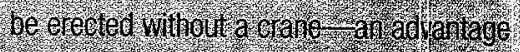

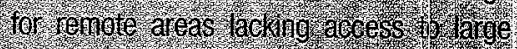
construction equininent?

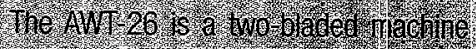

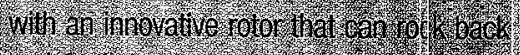

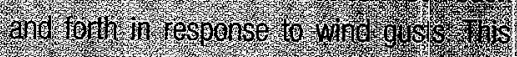

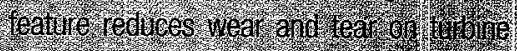

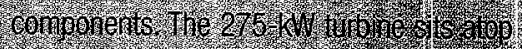

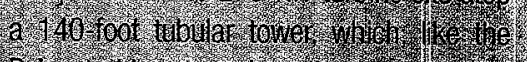

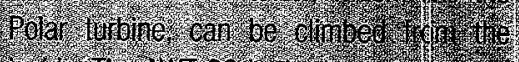

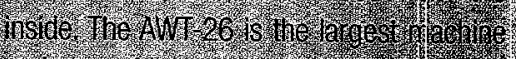

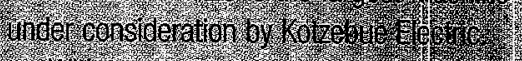

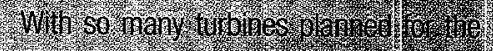

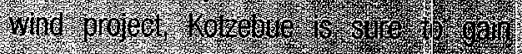

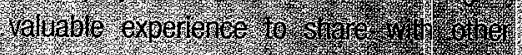

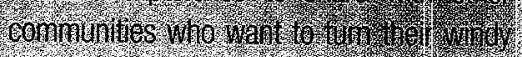
lecations into valiable assets: 
"This is not straightforward," Meiners says. "We're fortunate to have NREL helping us figure out how to take wind and [incorporate] it into a diesel system. This is a complicated control issue, not something you can solve by grabbing something off the shelf."

NREL selected special batteries that tolerate rapid discharge cycles and developed a computerized controller for the wind-diesel hybrid system, which will use diesel generators already operating in Wales. The controller will fine-tune the operation of the diesel generators, wind turbines, and batteries in response to changing wind conditions. The hybrid power system will save substantial amounts of diesel fuel by providing both electricity and heating. It is scheduled for installation during the summer and fall of 1998. The new power system will include two or three AOC 15/50 wind turbines with a wind energy capacity of 100 to $150 \mathrm{~kW}$.

"We picked the AOC 15/50 turbine for Wales because it's simple enough we can figure it out and fix it ourselves," Meiners says.

As Wales and Kotzebue gear up for their respective wind projects, their enthusiasm for wind is spreading to nearby communities. In response to this interest, the State of Alaska and Kotzebue Electric sponsored a workshop in the spring of 1998 for utilities interested in wind development. Workshop presenters discussed wind technologies and the opportunities they present to save on diesel fuel. They also highlighted the ways in which wind development creates new jobs.

"We believe the development of wind in northwest Alaska will provide employment opportunities for members of our communities," Reeve says. "When we displace expensive diesel fuel with wind, we save money. This is money we get to keep in our communities to build local economies and create jobs."

Reeve expects Atlantic Orient Corporation to train a cadre of local operations and maintenance workers (known as windsmiths) to keep Kotzebue's turbines in tip-top shape. Reeve says windsmiths from Kotzebue will then be able to use their skills throughout Alaska, in other states, and even in foreign countries.

"Lots of people around here--forest fire fighters, for instance-depend on 'on-call' employment," Reeve explains. "We've had fire crews from Alaska at every major national park forest fire, for example. Our folks are used to being available to work wherever they're needed-locally, nationally, basically anywhere in the world."

Atlantic Orient Corporation is enthusiastic about helping the economy in Kotzebue.

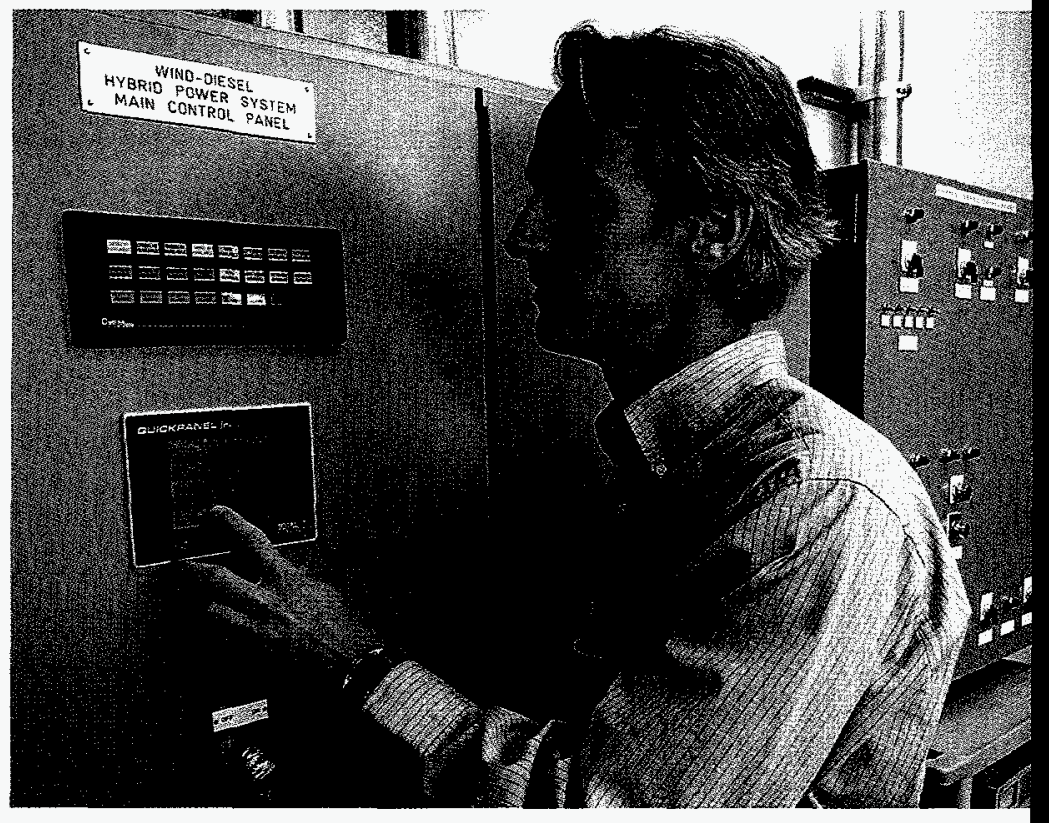

The National Wind Technology Center developed this village power system controller: The computerized controller makes it possible to adjust the operation of diesel generators to take account of changing wind conditions.

"We're going to do training so we can use Kotzebue windsmiths on other projects," says company President Bob Sherwin. "We're creating real jobs up there."

Reeve's vision of creating jobs with the wind technology project has impressed local residents, state officials, and DOE. Thanks to its many backers, Kotzebue may have as much as 2 megawatts of wind capacity by 2000 . That means Kotzebue residents could generate as much as two-thirds of their power from the wind on windy days.

That's good news. Diesel generation systems are too expensive for poor communities to afford if state energy subsidies disappear. And, even if they were affordable, diesel generators require the transport and storage of a fuel that poses a real threat to Alaska's land and coastal waters. Taking cost and environmental impacts into account, wind looks very good. It is less expensive than diesel generation. It protects, not harms, the environment. On top of all that, wind energy development is creating much-needed jobs. The next few years will show whether the technology can perform well in the Arctic climate. If so, wind power is sure to be a winner in Alaska. 
Working with industry to keep U.S. wind energy technology competitive in global markets.

THE U.S. DEPARTMENT OF ENERGY'S (DOE's) Office of Energy Efficiency and Renewable Energy manages the federal wind energy program in accordance with national energy policy. Wind diversifies the nation's energy supply, takes advantages of a domestic resource, and helps the nation meet its commitments to curb emissions of greenhouse gases, which threaten the stability of global climates. The federal wind energy program works with industry to keep U.S. wind energy technology competitive in global markets, thus strengthening the economy. The program includes a comprehensive wind energy research program, wind turbine research and development, and support for utilities, industry, and international wind energy projects. DOE's wind turbine research and development activities are described in $A$ New Generation of Wind Turbines on the Horizon on page 12.

DOE's field offices and national laboratories carry out program activities. The National Renewable Energy Laboratory (NREL), located in Golden, Colorado, is DOE's lead laboratory in wind technology research and development. Sandia National Laboratories (Sandia), located in Albuquerque, New Mexico, performs applied wind energy research. Both NREL and Sandia support the National Wind Technology Center (NWTC), located at NREL. The NWTC is the nation's only full-service wind turbine testing center.

The federal wind energy program helps engineers and scientists advance the technology needed to create new wind turbine designs, better understand how to integrate wind into utility systems, and improve U.S. technology to compete in global energy markets. Researchers explore the characteristics of the wind and how wind interacts with a turbine rotor, study the physical and chemical properties of the materials used to make blades and other turbine components, and advance the fundamental scientific principles needed to improve wind technology. As research engineers acquire a deeper understanding of these principles, this knowledge becomes the foundation for computer models and other design tools used to design new technology.

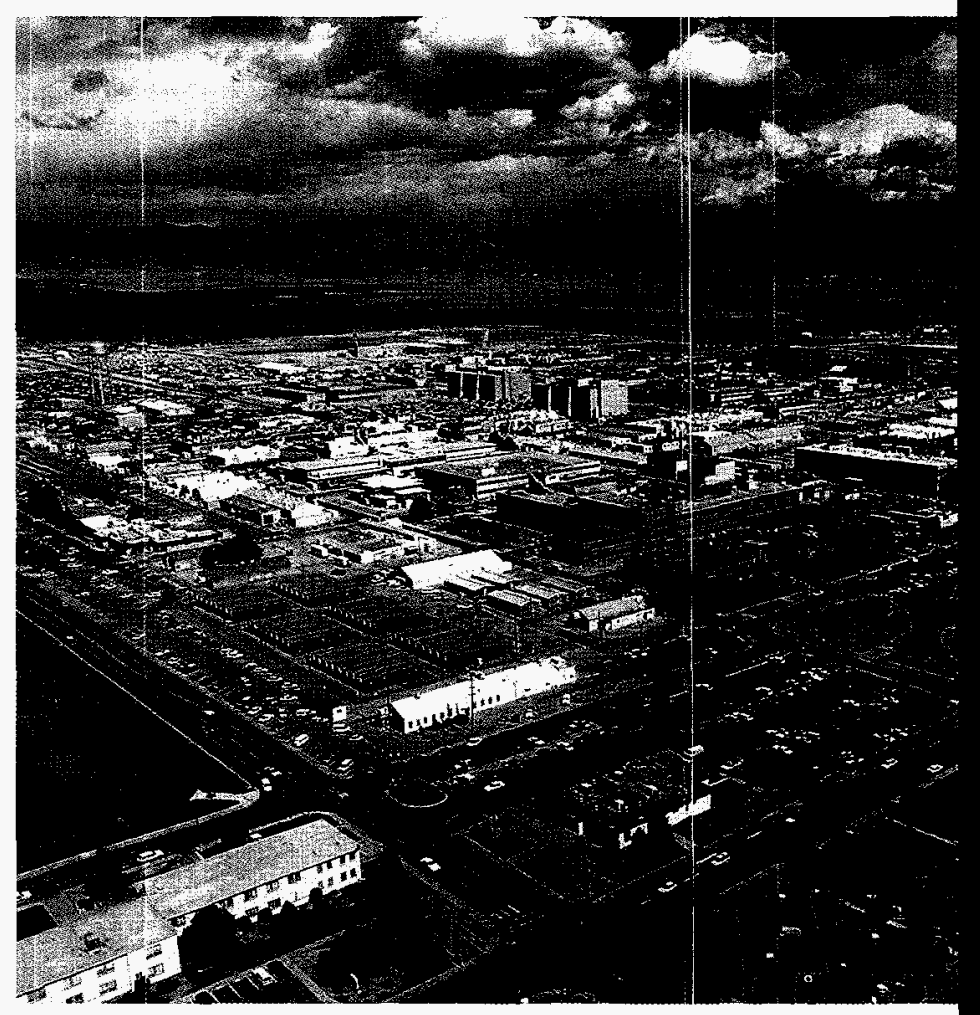

Left to rigbt: Sandia National Laboratories in Albuquerque, New Mexico; Nat

Researchers envision the wind technology that will be required by industry in 10 or 15 years, then plan research projects accordingly. Then, when companies ase ready to develop a new turbine, cuttingedge technologies and design tools are ready to help them go to market quickly with new products. The wind industry has neither the time nor the money to invest in long-term basic and applied research.

The following tools are some of those DOE is developing to help industry build better wind turbines:

- Computer Models. NREL, Sandia, and university researchers are developing a suite of design and analysis codes that will make it possible for designers to build a new turbine on the computer and refine it for commercialization without having to build and test prototype turbines.

- Advanced Controls. NRFL is modifying its computer models to include advanced controls. Advanced 


\section{rogram}

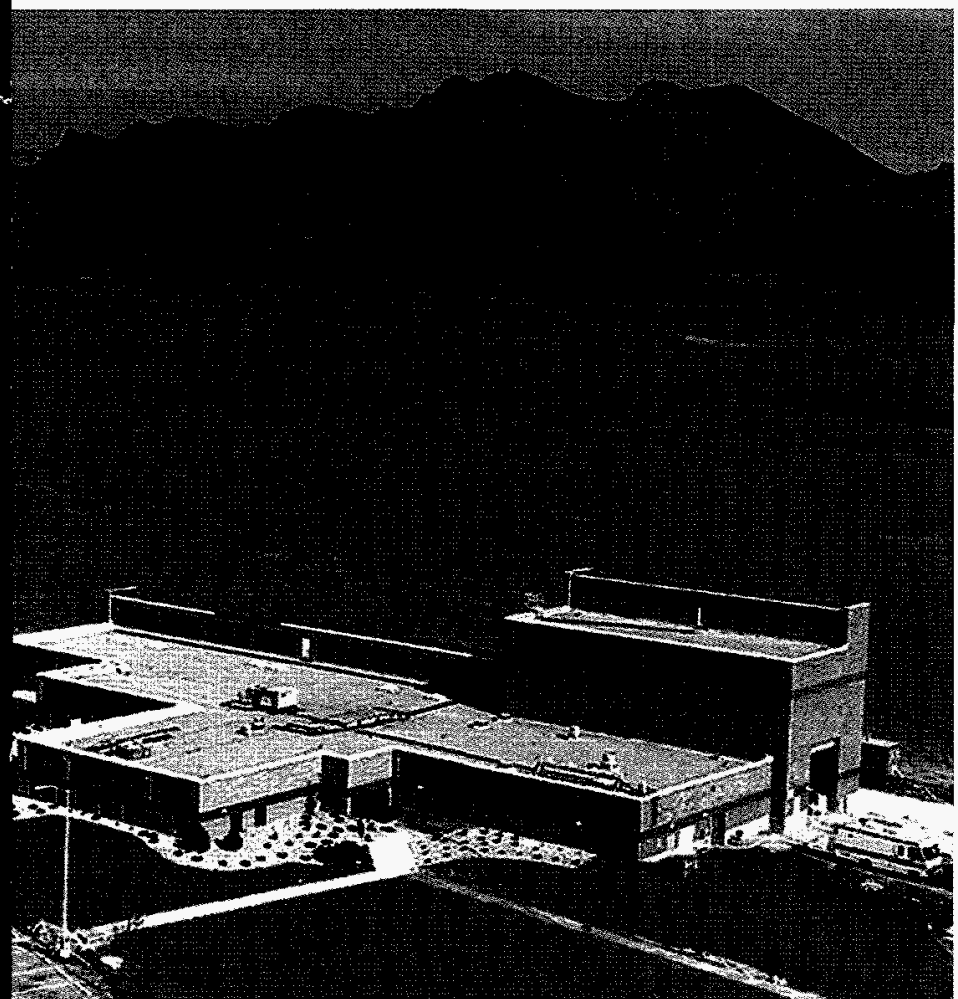

Technology Center near Golden, Colorado.

controls adjust turbine operation to maximize energy production and minimize wear and tear on the machine. In 1998, the laboratory created a new applied research team to lead an effort to develop smart controls for next-generation wind turbines.

- Adaptive Blades. Adaptive blades, which change shape in response to the wind, could increase turbine performance by as much as $35 \%$. Sandia researchers are investigating adaptive blade designs for constant- and variable-speed turbines.

- Advanced Research Turbines. A 600-kilowatt wind turbine at the NWTC is the first of several machines NREL will use for experiments to elucidate the basic scientific principles underlying wind power generation. NREL will also use the research turbines to develop advanced components and test promising technologies that the wind industry is unlikely to pursue because of cost or technical complexity.
The following research projects will help utilities better integrate wind power into their systems:

- Wind Forecasting. NREL researchers have shown that accurate wind forecasts could save utilities tens of millions of dollars a year by allowing them to predict wind generation for the next day. NREL and its utility partners are working on developing sophisticated wind-forecasting tools.

- Wind Integration Studies. NREL is developing tools to help utilities understand the effects of wind generation on conventional generation, transmission, distribution, and other utility services.

The following government programs are helping the U.S. wind industry compete in global energy markets:

- Certification Testing. NREL's National Wind Technology Center conducts certification testing for new wind turbines. Certification is required in Europe, India, and other major wind energy markets.

- Standards. Wind turbine sales abroad depend on American technology complying with international standards. NREL, Sandia, and the American Wind Energy Association are working with international organizations to establish standards for safety, power performance, and blade testing.

- Technical Assistance. DOE is bringing wind systems to areas where they are most needed by providing technical assistance in wind project planning and implementation. DOE also provides technical assistance for wind resource evaluations and technology development for international projects. NREL and Sandia are currently supporting wind projects in Argentina, Brazil, Chile, China, the Dominican Republic, India, Indonesia, Mexico, the Philippines, Russia, and South Africa.

The federal wind energy program and its partners in industry and academia play a crucial role in wind energy research, in the development of innovative wind technologies, and in the dissemination of these technologies throughout the world. In recognition of the importance of these efforts, Congress appropriated $\$ 28.6$ million to support the wind energy program in fiscal year 1997. 


\section{KEY CONTACTS}

\section{U.S. Department of Energy}

Peter Goldman

Acting Deputy Director

Office of Photovoltaic and

Wind Technologies, EE-11

1000 Independence Avenue, SW

Washington, DC 20585

\section{National Renewable Energy Laboratory} Robert Thresher

Director

National Wind Technology Center

1617 Cole Boulevard

Golden, C0 80401

(303) 384-6922

\section{Susan Hock}

Wind Energy Technology Program Manager

National Wind Technology Center

1617 Cole Boulevard

Golden, C0 80401

(303) 384-6950

\section{Sandia National Laboratories}

Henry Dodd

Wind Energy Technology Program Manager

P.0. Box 5800

Albuquerque, NM 87185-0708

(505) $844-5253$
NOTICE: This report was prepared as an account of work sponsored by an agency of the United States government. Neither the United States government nor any agency thereof, nor any of their employees, makes any warranty, expressed or implied, or assumes any legal liability or responsibility for the accuracy, completeness, or usefulness of any information, apparatus, product, or process disclosed, or represents that its use would not infringe privately owned rights. Reference herein to any specific commercial product, process, or service by trade name, trademark, manufacturer, or otherwise does not necessarily constitute or imply its endorsement, recommendation, or favoring by the United States government or any agency thereof. The views and opinions of authors expressed herein do not necessarily state or reflect those of the Lnited States government of any agency thereof.

Printed in the United States of America

Available to DOE and DOE contractors from:

Office of Scientific and Technical Information (OSTI)

P.O. Box 62

Oak Ridge, TN 37831

Prices available by calling (423) 576-8401

\section{Available from:}

National Technical Information Service

U.S. Department of Commerce

5285 Port Royal Road

Springfield, VA 22161

(703) $487-4650$

Information pertaining to the pricing codes can be found in the current issue of the following publications which are generally available in most libraries: Government Reports Announcements and Index (GRA and I); Scientific and Tecbnical Abstract Reports (STAR); and publication NTIS-PR-360 available from NTIS at the above address.

PHOTO CREDITS: Cover: PIX 05614 Les Wollam; pg. 3, PLX 05591 Green Mountain Power Corp.; pg. 4, PIX 05768 Green Mountain Power Corp.; pg. 6, left to right, PIX 04́694 Lloyd Herziger/En.ron Wind Corp., PIX 05593 Green Mountain Power Corp.; pg. 7, PIX 05614 Les Wollam; pg. 10, PIX 05767 Neil Kelley/NREL; pg. 11, PIX 05980 Brad Reeve/Kotzebue Electric Association; pg. 12, PIX 05613 Les Wollam; pgs. 14 and 15 , left to right, PIX 03838 Warren Gretz/NREL, PLX 01502 uloyd Herziger, PIX 00720 Warren Gretz/NREL; pg. 16, PLX 05764 Neil Kelley/ NREL; pg. 17, PIX 00361 David Parsons/NREL; pg. 19, PIX 05763 Warren Gretz/NREL; pgs. 22 and 23, 1. PrX 00350 Warren Gretz/NREL, 2. PIX 05776 Warren Gretz/NREL, 3. PIX 04788 Warren Gretz/NREL, 4. PIX 00335 Warren Gretz/NREL, 5. PIX 04119 Warren Gretz/NREL, 6. PLX 02142 Warren Gretz/NREL, 7. PIX 02131 Warren Gretz/NREL, 8. PIX 00640 Warren Gretz/NREL, 9. PIX 05310 Warren Gretz/NREL, 10. PIX 05979 Scott Hughes/NREL; pg. 24, 1998 Jeff Schultz/Alaska Stock; pg. 25, PIX 05628 Ian Baring-Gould/NREL; pg. 26, PIX 04684 Larry Flowers/NREL; pg. 27, left to right, PIX 05625 Warren Gretz/NREL, PIX 05627 Steve Drouilhet/NREL; pg. 28, PIX 05626 Steve Drouilhet/NREL; pg. 29, PIX 05631 Warren Gretz/NREL; pg. 30, top to bottom, PIX 05981 Warren Gretz/NREL, PIX 05629 lan Baring-Gould/NREL; pg. 31, PIX 05630 Warren Gretz/NREL; pg. 32 and inside back cover, left to right, PIX 04678 Sandia National Laboratories, PLX 00337 Warren Gretz/ NREL.

\section{WIND ENERGY PROGRAM WEB SITES:}

U.S. Department of Energy: http://www.erendoe.gov/wind National Renewable Energy Laboratory: http://www.nrel.gov/wind Sandia National Laboratories:

http:/www.sandia.gov/Renewable_Energy/wind_energy/homepage.html

Produced for the

U.S. Department of Energy

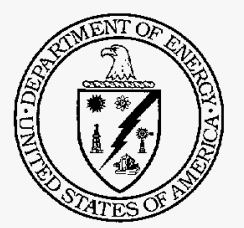

1000 Independence Avenue, SW Washington, DC 20585

by the

National Renewable Energy Laboratory,

a DOE national laboratory

DOE/GO-10098-550

April 1998 